\begin{abstract}
BUKU 2
ANALISIS PEMBELAJARAN

SILABUS

RPP

RANCANGAN TUGAS

PENILAIAN TUGAS

KONTRAK PEMBELAJARAN

RENCANA EVALUASI PROSES PEMBELAJARAN RENCANA EVALUASI PROSES PEMBELAJARAN REKONSTRUKSI MATA KULIAH

BAHAN AJAR
\end{abstract}

\title{
ILMU SOSIAL DASAR
}

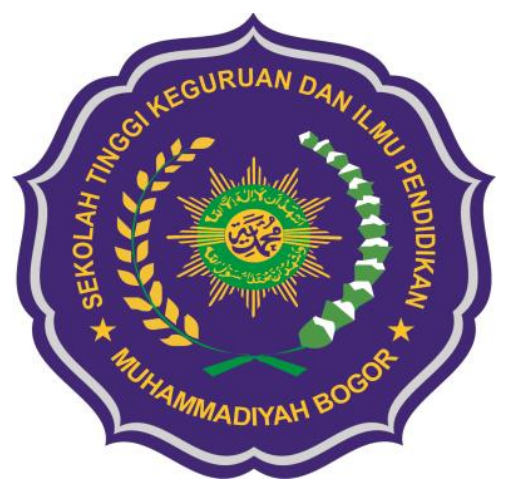

PENGAJAR : WAHYU BAGJA SULFEMI, SS.

STKIP MUHAMMADIYAH BOGOR 2007 


\section{LEMBAR PENGESAHAN}

JUDUL : ANALISIS PEMBELAJARAN

SILABUS

RPP

RANCANGAN TUGAS

PENILAIAN TUGAS

KONTRAK PEMBELAJARAN

RENCANA EVALUASI PROSES PEMBELAJARAN

NAMA : Wahyu Bagja Sulfemi, SS. 


\section{KATA PENGANTAR}

Puji syukur penulis panjatkan kehadirat Allah SWT. Karena atas kehendakNyalah penyusunan laporan pembuatan Analisis Pembelajaran, Silabus, Rencana Pelaksanaan Pembelajaran (RPP), Kontrak Pembelajaran dan Rancangan tugas test uraian/objektif dapat terselesaikan

Laporan ini disampaikan di dalam pelatihan Applied Approach (AA) bagi dosen perguruan tinggi swasta dilingkungan kopertis wilayah IV. Pelatihan dilaksanakan di lingkungan kantor Kopertis di Jatinangor, Sumedang.

Dalam kesempatan ini pula, perkenankan penulis menghaturkan penghormatan dan ucapan terimakasih kepada :

1. Ketua STKIP Muhammadiyah Bogor yang telah memberikan kesempatan kepada penulis untuk mengikuti pelatihan ini;

2. Karyawan rumah tangga Kopertis Wilayah IV Jawa Barat dan Banten yang telah memberikan pelayanan yang sangat baik;

3. Teman-teman dosen peserta kegiatan AA yang selalu memberikan masukan, dorongan dan motivasi dalam penyusunan tugas mandiri ini.

Semoga hasil tugas mandiri ini dapat bermanfaat untuk keperluan pengembangan ilmu pengetahuan. Akhirnya kepada Allah jualah penulis mohon taufik hidayah, semoga usaha kami ini mendapat manfaat yang baik. Serta mendapat ridho dari Allah SWT. Amin ya rabbal alamin.

Penulis,

Wahyu Bagja Sulfemi, SS., M. 


\section{DAFTAR ISI}

Lembar Pengesahan ...................................................................... i

Kata Pengantar ........................................................................... ii

Daftar Isi f............................................................................ iii

Analis is Pembelajaran ......................................................................... 1

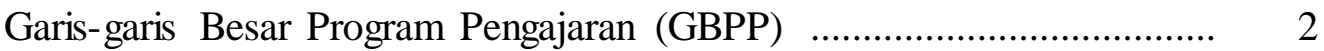

Rencana Program Pengajaran (RPP) …................................................. 4

Kontrak Perkuliahan ..................................................................... 18

Rancangan Tugas Pembelajaran .............................................................. 23

Kisi-kisi Tes Obyektif dan Test Uraian ................................................ 25 


\section{ANALISIS PEMBELAJARAN}

\section{Mata Kuliah Ilmu Sosial Dasar}

Judul Mata Kuliah

Nomor Kode MK

Jml SKS

DeskripsiSingkat

StandarKompetensi

Pengajar

\section{: Ilmu Sosial Dasar}

: MKK 100107

: 2 sks

: Mata kuliah Ilmu Sosial Dasar adalah salah satu dari mata kuliah kelompok Matakuliah Berkehidupan Bermasyarakat (MBB) di perguruan tinggi. Matakuliah ISD mengetengahkan pengetahuan dasar tentang konsep-konsep manusia, konsep-konsep kebudayaan, konsep-konsep sosiologi, konsep-konsep nilai, moral, dan hukum, dan konsep-konsep sains, teknoloi, seni, dan lingkungan

: Setelah mengikuti matakuliah ini mahasiswa dapat menjelaskan konsep-konsep social dan budaya dasar

: Wahyu Bagja Sulfemi, SS.,

\section{STANDAR KOMPETENSI}

Setelah mengikuti matakuliah ini, mahasiswa dapat menjelaskan konsep-konsep social dan budaya dasar

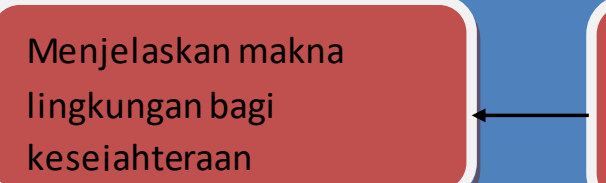

keseiahteraan
Merumuskan manusia sebagai mahluk berbudaya, beretika, dan berestetika
Menjelaskan manusia dan peradaban, dan dinamika peradaban
Menjelaskan perlunya ISBD sebagai matakuliah MBB sebagai solos problem sosbud
Merumuskan hakikat, fungsi, nilai, moral, dan hukum dalam upaya mendapatkan keadilan, ketertiban dan kesejahteraan masyarakat
Mendefinisikan hakikat manusia sebagai individu dan mahluk sosial
Menyebutkan hakikat keragaman dan kesetaraan dalam dinamika sosial 


\section{SILABUS}

MATA KULIAH

KODE MATA KULIAH

KREDIT

SEMESTER

PENANGGUNG JAWAB MK DESKRIPSI SINGKAT
: Ilmu Sosial Dasar

: MKK 100107

: $2 \mathrm{Sks}$

: 2 (dua)

: Wahyu Bagja Sulfemi, SS.

: Mata kuliah Ilmu Sosial Dasar adalah salah satu dari mata kuliah kelompok Matakuliah Berkehidupan Bermasyarakat (MBB) di perguruan tinggi. Matakuliah ISD mengetengahkan pengetahuan dasar tentang konsep-konsep manusia, konsep-konsep kebudayaan, konsep-konsep sosiologi, konsepkonsep nilai, moral, dan hukum, dan konsep-konsep sains, teknoloi, seni, dan lingkungan

STANDAR KOMPETENSI : Setelah mengikuti matakuliah ini mahasiswa dapat menjelaskan konsep-konsep social dan budaya dasar

\begin{tabular}{|c|c|c|c|c|c|c|c|}
\hline NO & $\begin{array}{c}\text { KOMPETEN } \\
\text { SI DASAR }\end{array}$ & $\begin{array}{c}\text { POKOK } \\
\text { BAHASAN } \\
\text { DALAM } \\
\text { MATA } \\
\text { KULIAH } \\
\end{array}$ & $\begin{array}{l}\text { SUB POKOK } \\
\text { BAHASAN }\end{array}$ & METODE & MEDIA & WAKTU & PUSTAKA \\
\hline 1 & $\begin{array}{l}\text { SETELAH } \\
\text { MENGIKUTI } \\
\text { POKOK } \\
\text { BAHASAN } \\
\text { INI, } \\
\text { MAHASISWA } \\
: \\
\text { dapat } \\
\text { menjelaskan } \\
\text { perlunya ISD } \\
\text { sebagai } \\
\text { matakuliah } \\
\text { MBB sebagai } \\
\text { solusi problem } \\
\text { social budaya. }\end{array}$ & $\begin{array}{l}\text { hakikat dan } \\
\text { ruang } \\
\text { lingkup ISD }\end{array}$ & $\begin{array}{l}\text { 1. Hakikat } \\
\text { dan } \\
\text { ruang } \\
\text { lingkup } \\
\text { ISD, ISD } \\
\text { sebagai } \\
\text { MBB, } \\
\text { pendekata } \\
\text { n } \\
\text { interdisipli } \\
\text { ner dalam } \\
\text { ilmu sosial } \\
\text { budaya, } \\
\text { ISD } \\
\text { sebagai } \\
\text { Alternatif } \\
\text { pemecaha } \\
\text { n masalah } \\
\text { Sosial } \\
\text { budaya }\end{array}$ & $\begin{array}{l}\text { Ceramah, } \\
\text { diskusi dan } \\
\text { tanya } \\
\text { jawab }\end{array}$ & $\begin{array}{l}\text { OHP- } \\
\text { OHT, } \\
\text { LAPTO } \\
\text { P- } \\
\text { LCD }\end{array}$ & $\begin{array}{l}100 \\
\text { MENIT }\end{array}$ & $\begin{array}{l}\text { B W dan } \\
\text { BA }\end{array}$ \\
\hline
\end{tabular}




\begin{tabular}{|c|c|c|c|c|c|c|c|}
\hline & & & & & & & \\
\hline 2 & $\begin{array}{l}\text { Merumuskan } \\
\text { dan } \\
\text { mengespresika } \\
\text { n manusia } \\
\text { sebagai mahluk } \\
\text { berbudaya, } \\
\text { beretika, dan } \\
\text { berestetika }\end{array}$ & $\begin{array}{l}\text { manusia } \\
\text { sebagai } \\
\text { mahluk } \\
\text { berbudaya, } \\
\text { beretika, dan } \\
\text { berestetika }\end{array}$ & $\begin{array}{ll}\text { 2. } & \text { Hakikat } \\
\text { manusia } \\
\text { sebagai } \\
\text { mahluk } \\
\text { budaya } \\
\text { dan } \\
\text { Apresiasi } \\
\text { kemanusia } \\
\text { an dan } \\
\text { kebudayaa } \\
\text { n } \\
\text { 3. Etika dan } \\
\text { Estetika } \\
\text { budaya, } \\
\text { Konsep- } \\
\text { konsep } \\
\text { dasar } \\
\text { manusia } \\
\text { dan } \\
\text { memanusi } \\
\text { kan } \\
\text { manusia }\end{array}$ & $\begin{array}{l}\text { Ceramah, } \\
\text { diskusi dan } \\
\text { tanya } \\
\text { jawab }\end{array}$ & $\begin{array}{l}\text { OHP- } \\
\text { OHT, } \\
\text { LAPTO } \\
\text { P- } \\
\text { LCD }\end{array}$ & $\begin{array}{l}100 \\
\text { menit }\end{array}$ & $\begin{array}{l}\text { B W dan } \\
\text { BA }\end{array}$ \\
\hline 3 & $\begin{array}{l}\text { dapat } \\
\text { mendefinisikan } \\
\text { hakikat } \\
\text { manusia } \\
\text { sebagai } \\
\text { individu dan } \\
\text { mahluk sosial }\end{array}$ & $\begin{array}{l}\text { hakikat } \\
\text { manusia } \\
\text { sebagai } \\
\text { individu dan } \\
\text { mahluk sosial }\end{array}$ & $\begin{array}{ll}\text { 4. } & \text { Hakikat } \\
\text { manusia } \\
\text { sebagai } \\
\text { individu } \\
\text { dan } \\
\text { mahluk } \\
\text { sosial dan } \\
\text { Fungsi dan } \\
\text { peran } \\
\text { manusia } \\
\text { sebagai } \\
\text { individu } \\
\text { dan } \\
\text { mahluk } \\
\text { sosial } \\
\text { 5. Dinamika } \\
\text { interaksi } \\
\text { sosial dan } \\
\text { Dilema } \\
\text { kepentinga } \\
\text { n individu } \\
\text { dan } \\
\text { masyaraka } \\
\text { t } \\
\end{array}$ & $\begin{array}{l}\text { Ceramah, } \\
\text { diskusi dan } \\
\text { tanya } \\
\text { jawab }\end{array}$ & $\begin{array}{l}\text { OHP- } \\
\text { OHT, } \\
\text { LAPTO } \\
\text { P- } \\
\text { LCD }\end{array}$ & $\begin{array}{l}100 \\
\text { menit }\end{array}$ & $\begin{array}{l}\text { B W dan } \\
\text { BA }\end{array}$ \\
\hline 4 & $\begin{array}{l}\text { dapat } \\
\text { menjelaskan } \\
\text { manusia dan } \\
\text { peradaban, dan } \\
\text { dinamika }\end{array}$ & $\begin{array}{l}\text { hakikat } \\
\text { manusia dan } \\
\text { peradaban, } \\
\text { serta } \\
\text { dinamika }\end{array}$ & $\begin{array}{ll}6 . & \text { Hakikat } \\
\text { peradaban } \\
\text { Mahluk } \\
\text { beradab } \\
\text { dan }\end{array}$ & $\begin{array}{l}\text { Ceramah, } \\
\text { diskusi dan } \\
\text { tanya } \\
\text { jawab }\end{array}$ & $\begin{array}{l}\text { OHP- } \\
\text { OHT, } \\
\text { LAPTO } \\
\text { P- } \\
\text { LCD }\end{array}$ & $\begin{array}{l}100 \\
\text { menit }\end{array}$ & $\begin{array}{l}\text { B W dan } \\
\text { BA }\end{array}$ \\
\hline
\end{tabular}




\begin{tabular}{|c|c|c|c|c|c|c|c|}
\hline & $\begin{array}{l}\text { peradaban } \\
\text { global }\end{array}$ & $\begin{array}{l}\text { peradaban } \\
\text { global }\end{array}$ & $\begin{array}{l}\text { masyaraka } \\
\text { t beradab } \\
\text { 7. } \\
\text { Evolusi } \\
\text { budaya } \\
\text { dan wujud } \\
\text { peradaban } \\
\text { Dinamika } \\
\text { peradaban } \\
\text { global } \\
\text { serta } \\
\text { Problemati } \\
\text { ka } \\
\text { peradaban }\end{array}$ & & & & \\
\hline & UTS & & 8. $\quad$ Materi1 -7 & & & & \\
\hline 5 & $\begin{array}{l}\text { dapat } \\
\text { menyebutkan } \\
\text { hakikat } \\
\text { keragaman dan } \\
\text { kesetaraan } \\
\text { dalam } \\
\text { dinamika sosial } \\
\text { manusia }\end{array}$ & $\begin{array}{l}\text { hakikat } \\
\text { keragaman } \\
\text { dan } \\
\text { kesetaraan } \\
\text { dalam } \\
\text { dinamika } \\
\text { sosial } \\
\text { manusia }\end{array}$ & $\begin{array}{ll}\text { 9. } & \text { Hakikat } \\
\text { keragaman } \\
\text { dan } \\
\text { kesetaraan } \\
\text { manusia } \\
\text { dan } \\
\text { Kemajemu } \\
\text { kan dalam } \\
\text { dinamika } \\
\text { sosial } \\
\text { budaya } \\
\text { 10. Keragama } \\
\text { n dan } \\
\text { kesetaraan } \\
\text { sebagai } \\
\text { kekayaan } \\
\text { sosial } \\
\text { budaya } \\
\text { Problemati } \\
\text { ka } \\
\text { keragaman } \\
\text { dan } \\
\text { kesetaraan } \\
\end{array}$ & $\begin{array}{l}\text { Ceramah, } \\
\text { diskusi dan } \\
\text { tanya } \\
\text { jawab }\end{array}$ & $\begin{array}{l}\text { OHP- } \\
\text { OHT, } \\
\text { LAPTO } \\
\text { P- } \\
\text { LCD }\end{array}$ & $\begin{array}{l}100 \\
\text { menit }\end{array}$ & $\begin{array}{l}\text { B W dan } \\
\text { BA }\end{array}$ \\
\hline 6 & $\begin{array}{l}\text { dapat } \\
\text { merumuskan } \\
\text { hakikat, fungsi, } \\
\text { nilai, moral, } \\
\text { dan hukum } \\
\text { dalam upaya } \\
\text { mendapatkan } \\
\text { keadilan, } \\
\text { ketertiban dan } \\
\text { kesejahteraan } \\
\text { masyarakat }\end{array}$ & $\begin{array}{l}\text { hakikat, } \\
\text { fungsi, nilai, } \\
\text { moral, dan } \\
\text { hukum dalam } \\
\text { upaya } \\
\text { mendapatkan } \\
\text { keadilan, } \\
\text { ketertiban } \\
\text { dan } \\
\text { kesejahteraan } \\
\text { masyarakat }\end{array}$ & $\begin{array}{l}\text { 11. Mengkaji } \\
\text { hakikat, } \\
\text { fungsi, } \\
\text { nilai, } \\
\text { moral dan } \\
\text { hukum } \\
\text { dan } \\
\text { Mengkaji } \\
\text { keadilan, } \\
\text { ketertiban } \\
\text { dan } \\
\text { kesejahter } \\
\text { aan } \\
\text { 12. Mengident } \\
\text { ifikasi }\end{array}$ & $\begin{array}{l}\text { Ceramah, } \\
\text { diskusi dan } \\
\text { tanya } \\
\text { jawab }\end{array}$ & $\begin{array}{l}\text { OHP- } \\
\text { OHT, } \\
\text { LAPTO } \\
\text { P - } \\
\text { LCD }\end{array}$ & $\begin{array}{l}100 \\
\text { menit }\end{array}$ & $\begin{array}{l}\text { B W dan } \\
\text { BA }\end{array}$ \\
\hline
\end{tabular}




\begin{tabular}{|c|c|c|c|c|c|c|c|}
\hline & & & $\begin{array}{l}\text { perwujuda } \\
\text { n } \\
\text { masyaraka } \\
\text { t bermoral } \\
\text { dan taat } \\
\text { hukum } \\
\text { serta } \\
\text { problemati } \\
\text { ka nilai, } \\
\text { moral, dan } \\
\text { hukum }\end{array}$ & & & & \\
\hline 7. & $\begin{array}{l}\text { dapat } \\
\text { menguraikan } \\
\text { hakikat dan } \\
\text { makna sains, } \\
\text { teknologi, dan } \\
\text { seni, dan } \\
\text { dampak dan } \\
\text { pemanfaatan } \\
\text { teknologi di } \\
\text { Indonesia }\end{array}$ & $\begin{array}{l}\text { hakikat dan } \\
\text { makna sains, } \\
\text { teknologi, } \\
\text { dan seni, dan } \\
\text { dampak dan } \\
\text { pemanfaatan } \\
\text { teknologi di } \\
\text { Indonesia }\end{array}$ & $\begin{array}{l}\text { 13. Hakikat } \\
\text { dan makna } \\
\text { sains, } \\
\text { teknologi, } \\
\text { dan seni } \\
\text { bagi } \\
\text { manusia } \\
\text { 14. Dampak } \\
\text { penyalahg } \\
\text { una-an } \\
\text { IPTEKS } \\
\text { pada } \\
\text { kehidupan } \\
\text { sosbud } \\
\text { serta } \\
\text { Problemati } \\
\text { ka } \\
\text { pemanfaat } \\
\text { an } \\
\text { IPTEKS di } \\
\text { Indone }\end{array}$ & $\begin{array}{l}\text { Ceramah, } \\
\text { diskusi dan } \\
\text { tanya } \\
\text { jawab }\end{array}$ & $\begin{array}{l}\text { OHP- } \\
\text { OHT, } \\
\text { LAPTO } \\
\text { P- } \\
\text { LCD }\end{array}$ & $\begin{array}{l}100 \\
\text { menit }\end{array}$ & $\begin{array}{l}\text { B W dan } \\
\text { BA }\end{array}$ \\
\hline 8. & $\begin{array}{l}\text { dapat } \\
\text { menguraian } \\
\text { hakikat dan } \\
\text { makna } \\
\text { lingkungan } \\
\text { bagi } \\
\text { kesejahteraan }\end{array}$ & $\begin{array}{l}\text { hakikat dan } \\
\text { makna } \\
\text { lingkungan } \\
\text { bagi } \\
\text { kesejahteraan }\end{array}$ & $\begin{array}{l}\text { 15. Hakikat } \\
\text { dan makna } \\
\text { lingkunga } \\
\mathrm{n} \text { bagi } \\
\text { manusia } \\
\text { dan } \\
\text { Kualitas } \\
\text { penduduk } \\
\text { dan } \\
\text { lingkunga } \\
\mathrm{n} \text { terhadap } \\
\text { kesejahter } \\
\text { aan } \\
\text { 16. Problema } \\
\text { lingkunga } \\
\mathrm{n} \text { sosial } \\
\text { budaya } \\
\text { dan Isu-isu } \\
\text { penting } \\
\text { tentang } \\
\end{array}$ & $\begin{array}{l}\text { Ceramah, } \\
\text { diskusi dan } \\
\text { tanya } \\
\text { jawab }\end{array}$ & $\begin{array}{l}\text { OHP- } \\
\text { OHT, } \\
\text { LAPTO } \\
\text { P- } \\
\text { LCD }\end{array}$ & $\begin{array}{l}100 \\
\text { menit }\end{array}$ & $\begin{array}{l}\text { B W dan } \\
\text { BA }\end{array}$ \\
\hline
\end{tabular}




\begin{tabular}{|l|l|l|l|l|l|l|l|}
\hline & & $\begin{array}{c}\text { lintas } \\
\text { budaya } \\
\text { dan } \\
\text { bangsa }\end{array}$ & & & & & \\
\hline & & & $\begin{array}{c}\text { 17. Materi ke } \\
\text { 9-15 UAS }\end{array}$ & & & & \\
\hline
\end{tabular}




\section{RENCANA PROGRAM PEMBELAJARAN \\ (RPP)}

$\begin{array}{ll}\text { Mata kuliah } & \text { : Ilmu Sosial Dasar } \\ \text { Kode Matakuliah } & : \text { MKK } 100107 \\ \text { sks } & : 2 \\ \text { Waktu pertemuan } & : 2 \text { X } 50 \text { menit }\end{array}$

A. Tujuan

1. Standar Kompetensi

mahasiswa dapat menjelaskan konsep-konsep social : dan budaya dasar

2. Kompetensi Dasar

: Menjelaskan perlunya ISD sebagai matakuliah MBB sebagai solosi problem social budaya

B. Pokok Bahasan : Hakikat dan ruang lingkup ISD

C. Sub Pokok Bahasan : Hakikat dan ruang lingkup ISD

Pentingnya pendekatan interdisipliner dalam ilmu sosial budaya

ISD sebagai solosi problem social budaya

D. Kegiatan Belajar Mengajar : Pertemuan ke 1 (satu)

\begin{tabular}{|l|l|l|l|l|}
\hline $\begin{array}{c}\text { TAHAP } \\
\text { KEGIATAN }\end{array}$ & $\begin{array}{c}\text { KEGIATAN } \\
\text { DOSEN }\end{array}$ & $\begin{array}{c}\text { KEGIATAN } \\
\text { MAHASISWA }\end{array}$ & WAKTU & $\begin{array}{c}\text { MEDIA DAN } \\
\text { ALAT } \\
\text { PENGAJARAN }\end{array}$ \\
\hline Pendahuluan & $\begin{array}{c}\text { 1. Mengucapkan } \\
\text { salam dan } \\
\text { menjelaskan } \\
\text { cakupan } \\
\text { materi } \\
\text { pertemuan } \\
\text { ke-1; }\end{array}$ & $\begin{array}{l}\text { Memperhatikan } \\
\text { dan diskusi. }\end{array}$ & 10 Menit & $\begin{array}{l}\text { Laptop, } \\
\text { LCD/Infocus dan } \\
\text { White board. }\end{array}$ \\
& $\begin{array}{l}\text { 2. Menjelaskan } \\
\text { manfaat } \\
\text { materi }\end{array}$ & & \\
& pertemuan & & \\
ke-1; & & & \\
& 3. Relevansi & & \\
antara & & & \\
\end{tabular}




\begin{tabular}{|l|l|l|l|l|}
\hline & $\begin{array}{l}\text { standart } \\
\text { kompetensi } \\
\text { dengan } \\
\text { kompetensi } \\
\text { dasar. }\end{array}$ & & & \\
\hline Penyajian & $\begin{array}{l}\text { 4. Menjelaskan. } \\
\text { Hakikat dan } \\
\text { ruang } \\
\text { lingkup ISD }\end{array}$ & $\begin{array}{l}\text { Memperhatikan } \\
\text { dan diskusi. }\end{array}$ & 80 Menit & $\begin{array}{l}\text { Laptop, } \\
\text { LCD/Infocus dan } \\
\text { White board. }\end{array}$ \\
\hline Penutup & $\begin{array}{l}\text { 5. Menunjuk } \\
\text { beberapa } \\
\text { mahasiswa } \\
\text { secara acak } \\
\text { untuk } \\
\text { menjawab } \\
\text { pertanyaan. }\end{array}$ & $\begin{array}{l}\text { Menjawab } \\
\text { pertanyaan. }\end{array}$ & 10 Menit & \\
& & & \\
\hline
\end{tabular}

E. EVALUASI : 1. Jelaskan pengertian, tujuan \& fungsi ilmu sosial budaya dasar?

2. Jelaskan pendekatan interdisipliner dalam ilmu sosial budaya 


\title{
RENNCANA PROGRAM PEMBELAJARAN
}

(RPP)

\author{
Mata kuliah : Ilmu Sosial Dasar \\ Kode Matakuliah : : MKK 100107 \\ sks $\quad: 2$
}

Waktu pertemuan $\quad: 2 \times 50$ menit
A. Tujuan
1. Standar Kompetensi
Mahasiswa dapat menjelaskan konsep-konsep social : dan budaya

2. Kompetensi Dasar

: Merumuskan manusia sebagai mahluk berbudaya, beretika, dan berestetika

B. Pokok Bahasan

: Manusia sebagai mahluk berbudaya, beretika, dan berestetika

C. Sub Pokok Bahasan : $\quad$ 1. Hakikat Manusia sebagai mahluk budaya.

2. Apresiasi terhadap kemanusiaan.

D. Kegiatan Belajar Mengajar : Pertemuan ke 2 (dua)

\begin{tabular}{|c|c|c|c|c|}
\hline $\begin{array}{c}\text { TAHAP } \\
\text { KEGIATAN }\end{array}$ & $\begin{array}{c}\text { KEGIATAN } \\
\text { DOSEN }\end{array}$ & $\begin{array}{l}\text { KEGIATAN } \\
\text { MAHASISWA }\end{array}$ & WAKTU & $\begin{array}{c}\text { MEDIA DAN } \\
\text { ALAT } \\
\text { PENGAJARAN }\end{array}$ \\
\hline Pendahuluan & $\begin{array}{l}\text { 1. Mengucapkan } \\
\text { salam dan } \\
\text { menjelaskan } \\
\text { cakupan materi } \\
\text { pertemuan ke- } \\
2 \text {; } \\
\text { 2. Menjelaskan } \\
\text { manfaat materi } \\
\text { pertemuan ke- } \\
2 \text {; } \\
\text { 3. Relevansi } \\
\text { antara standart } \\
\text { kompetensi } \\
\text { dengan } \\
\text { kompetensi } \\
\text { dasar. }\end{array}$ & $\begin{array}{l}\text { Memperhatikan } \\
\text { dan diskusi. }\end{array}$ & 10 Menit & $\begin{array}{l}\text { Laptop, } \\
\text { LCD/Infocus dan } \\
\text { White board. }\end{array}$ \\
\hline Penyajian & 1. Menjelaskan & Memperhatikan & 75 Menit & Laptop, \\
\hline
\end{tabular}




\begin{tabular}{|l|l|l|l|l|}
\hline & $\begin{array}{l}\text { Hakikat } \\
\text { manusia } \\
\text { sebagai mahluk } \\
\text { budaya dan } \\
\text { Apresiasi } \\
\text { kemanusiaan } \\
\text { terhadap } \\
\text { kebudayaan }\end{array}$ & dan diskusi. & & $\begin{array}{l}\text { LCD/Infocus dan } \\
\text { White board. }\end{array}$ \\
\hline Penutup & $\begin{array}{l}\text { 2. Menunjuk } \\
\text { beberapa } \\
\text { mahasiswa } \\
\text { secara acak } \\
\text { untuk } \\
\text { menjawab } \\
\text { pertanyaan. }\end{array}$ & $\begin{array}{l}\text { Menjawab } \\
\text { pertanyaan, } \\
\text { memberikan } \\
\text { pendapat dan } \\
\text { memperhatikan }\end{array}$ & \multirow{2}{*}{15 Menit } & \\
& & & \\
\hline
\end{tabular}

E. EVALUASI : 1. Jelaskan yang dimaksud dengan hakikat manusia sebagai mahluk budaya

2. Jelaskan Apresiasi manusia terhadap kebudayaan 


\title{
RENCANA PROGRAM PEMBELAJARAN
}

(RPP)

\author{
Mata kuliah : Ilmu Sosial Dasar \\ Kode Matakuliah $\quad$ : MKK 100107 \\ sks $\quad: 2$
}

Waktu pertemuan $: 2 \times 50$ menit

\section{A. Tujuan}

1.Standar Kompetensi Mahasiswa dapat menjelaskan konsep-konsep social : dan budaya dasar

2. Kompetensi Dasar

B. Pokok Bahasan

C. Sub Pokok Bahasan
: Merumuskan manusia sebagai mahluk berbudaya, beretika, dan berestetika

: manusia sebagai mahluk berbudaya, beretika, dan berestetika

: Etika dan Estetika budaya, Konsep-konsep dasar manusia dan memanusikan manusia

D. Kegiatan Belajar Mengajar : Pertemuan ke 3 (tiga)

\begin{tabular}{|c|c|c|c|c|}
\hline $\begin{array}{c}\text { TAHAP } \\
\text { KEGIATAN }\end{array}$ & $\begin{array}{l}\text { KEGIATAN } \\
\text { DOSEN }\end{array}$ & $\begin{array}{l}\text { KEGIATAN } \\
\text { MAHASISWA }\end{array}$ & WAKTU & $\begin{array}{c}\text { MEDIA DAN } \\
\text { ALAT } \\
\text { PENGAJARAN }\end{array}$ \\
\hline Pendahuluan & $\begin{array}{l}\text { 1. Mengucapkan } \\
\text { salam dan } \\
\text { menjelaskan } \\
\text { cakupan materi } \\
\text { pertemuan ke- } \\
\text { 3; } \\
\text { 2. Menjelaskan } \\
\text { manfaat materi } \\
\text { pertemuan ke- } \\
\text { 3; } \\
\text { 3. Relevansi } \\
\text { antara standart } \\
\text { kompetensi } \\
\text { dengan } \\
\text { kompetensi } \\
\text { dasar. }\end{array}$ & $\begin{array}{l}\text { Memperhatikan } \\
\text { dan diskusi. }\end{array}$ & 10 Menit & $\begin{array}{l}\text { Laptop, } \\
\text { LCD/Infocus dan } \\
\text { White board. }\end{array}$ \\
\hline Penyajian & $\begin{array}{l}\text { 4. Menjelaskan } \\
\text { etika dan }\end{array}$ & Memperhatikan & 75 Menit & $\begin{array}{l}\text { Laptop, } \\
\text { LCD/Infocus dan }\end{array}$ \\
\hline
\end{tabular}




\begin{tabular}{|l|l|l|l|l|}
\hline & $\begin{array}{l}\text { estetika budaya } \\
\text { dan Konsep- } \\
\text { konsep dasar } \\
\text { manusia dan } \\
\text { Problema } \\
\text { kebudayaan }\end{array}$ & & & \\
& $\begin{array}{l}\text { Menunjuk } \\
\text { beberapa } \\
\text { mahasiswa } \\
\text { secara acak } \\
\text { Pntuk } \\
\text { menjawab } \\
\text { pertanyaan. }\end{array}$ & $\begin{array}{l}\text { Menjawab } \\
\text { pertanyaan, } \\
\text { memberikan } \\
\text { pendapat dan } \\
\text { memperhatikan }\end{array}$ & \multirow{2}{*}{15 Menit } & \\
& & & \\
& & & \\
& & & \\
\hline
\end{tabular}

E. EVALUASI : 1. konsep dasar manusia dalam memanusikan manusia 2. Jelaskan Etika dan Estetika dalam budaya 


\title{
RENCANA PROGRAM PEMBELAJARAN
}

(RPP)

\author{
Mata kuliah : Ilmu Sosial Dasar \\ Kode Matakuliah : : MKK 100107 \\ sks $\quad: 2$
}

Waktu pertemuan $\quad: 2 \times 50$ menit

\section{A. Tujuan}

1. Standar Kompetensi

Mahasiswa dapat menjelaskan konsep-konsep social : dan budaya dasar

2. Kompetensi Dasar

B. Pokok Bahasan

C. Sub Pokok Bahasan
: Mendefinisikan hakikat manusia sebagai individu dan mahluk sosial

: hakikat manusia sebagai individu dan mahluk sosial

: Hakikat manusia sebagai individu dan mahluk sosial. Fungsi dan peran manusia sebagai individu dan mahluk sosial

D. Kegiatan Belajar Mengajar : Pertemuan ke 4 (Empat)

\begin{tabular}{|c|c|c|c|c|}
\hline $\begin{array}{c}\text { TAHAP } \\
\text { KEGIATAN }\end{array}$ & $\begin{array}{l}\text { KEGIATAN } \\
\text { DOSEN }\end{array}$ & $\begin{array}{l}\text { KEGIATAN } \\
\text { MAHASISWA }\end{array}$ & WAKTU & $\begin{array}{c}\text { MEDIA DAN } \\
\text { ALAT } \\
\text { PENGAJARAN }\end{array}$ \\
\hline Pendahuluan & $\begin{array}{l}\text { 1. Mengucapk } \\
\text { an salam } \\
\text { dan } \\
\text { menjelaska } \\
\text { n cakupan } \\
\text { materi } \\
\text { pertemuan } \\
\text { ke-4; } \\
\text { 2. Menjelaska } \\
\text { n manfaat } \\
\text { materi } \\
\text { pertemuan } \\
\text { ke-4; } \\
\text { 3. Relevansi } \\
\text { antara } \\
\text { standart } \\
\text { kompetensi } \\
\text { dengan } \\
\text { kompetensi }\end{array}$ & $\begin{array}{l}\text { Memperhatikan } \\
\text { dan diskusi. }\end{array}$ & 10 Menit & $\begin{array}{l}\text { Laptop, } \\
\text { LCD/Infocus dan } \\
\text { White board. }\end{array}$ \\
\hline
\end{tabular}




\begin{tabular}{|c|c|c|c|c|}
\hline & dasar. & & & \\
\hline Penyajian & $\begin{array}{l}\text { 1. Menjelaska } \\
\text { n Hakikat } \\
\text { manusia } \\
\text { sebagai } \\
\text { individu } \\
\text { dan mahluk } \\
\text { sosial dan } \\
\text { Fungsi dan } \\
\text { peran } \\
\text { manusia } \\
\text { sebagai } \\
\text { individu } \\
\text { dan mahluk } \\
\text { sosial }\end{array}$ & $\begin{array}{l}\text { Memperhatikan } \\
\text { dan diskusi. }\end{array}$ & 75 Menit & $\begin{array}{l}\text { Laptop, } \\
\text { LCD/Infocus dan } \\
\text { White board. }\end{array}$ \\
\hline Penutup & $\begin{array}{l}\text { 2. Menunjuk } \\
\text { beberapa } \\
\text { mahasiswa } \\
\text { secara acak } \\
\text { untuk } \\
\text { menjawab } \\
\text { pertanyaan. }\end{array}$ & $\begin{array}{l}\text { Menjawab } \\
\text { pertanyaan, } \\
\text { memberikan } \\
\text { pendapat dan } \\
\text { memperhatikan }\end{array}$ & 15 Menit & \\
\hline
\end{tabular}

E. EVALUASI

F. REFERENSI
: 1. Jelaskan Hakikat manusia sebagai individu dan mahluk sosial

2. Jelaskan Fungsi dan peran manusia sebagai individu dan mahluk sosial

: 1. Schuon, F. 1997. Hakikat Manusia. Pustaka Pelajar. Yogakarta.

2. Soekanto, Soejono. 1983. Struktur Masyarakat. Rajawali. Jakart

3. Setiadi, Elly M. dkk. 2006. ISD. Kencana. Jakarta.

4. Suleman, munandar. 1995. Ilmu Budaya Dasar. Eresco. Bandung. 


\title{
RENCANA PROGRAM PEMBELAJARAN
}

(RPP)

\author{
Mata kuliah : Ilmu Sosial Dasar \\ Kode Matakuliah : : MKK 100107 \\ sks $\quad: 2$
}

Waktu pertemuan $\quad: 2 \times 50$ menit
A. Tujuan
1. Standar Kompetensi
Mahasiswa dapat menjelaskan konsep-konsep social
: dan budaya dasar
2. Kompetensi Dasar
: Mendefinisikan hakikat manusia sebagai individu dan mahluk sosial
B. Pokok Bahasan
: hakikat manusia sebagai individu dan mahluk sosial
C. Sub Pokok Bahasan
: Dinamika interaksi sosial dan Dilema kepentingan individu dan masyarakat

D. Kegiatan Belajar Mengajar : Pertemuan ke 5 (lima)

\begin{tabular}{|c|c|c|c|c|}
\hline $\begin{array}{c}\text { TAHAP } \\
\text { KEGIATAN }\end{array}$ & $\begin{array}{l}\text { KEGIATAN } \\
\text { DOSEN }\end{array}$ & $\begin{array}{c}\text { KEGIATAN } \\
\text { MAHASISWA }\end{array}$ & WAKTU & $\begin{array}{c}\text { MEDIA DAN } \\
\text { ALAT } \\
\text { PENGAJARAN }\end{array}$ \\
\hline Pendahuluan & $\begin{array}{l}\text { 1. Mengucapkan } \\
\text { salam dan } \\
\text { menjelaskan } \\
\text { cakupan } \\
\text { materi } \\
\text { pertemuan ke- } \\
5 \text {; } \\
\text { 2. Menjelaskan } \\
\text { manfaat } \\
\text { materi } \\
\text { pertemuan ke- } \\
\text { 5; } \\
\text { 3. Relevansi } \\
\text { antara standart } \\
\text { kompetensi }\end{array}$ & $\begin{array}{l}\text { Memperhatikan } \\
\text { dan diskusi. }\end{array}$ & 10 Menit & $\begin{array}{l}\text { Laptop, } \\
\text { LCD/Infocus dan } \\
\text { White board. }\end{array}$ \\
\hline
\end{tabular}




\begin{tabular}{|l|l|l|l|l|}
\hline & $\begin{array}{l}\text { dengan } \\
\text { kompetensi } \\
\text { dasar. }\end{array}$ & & \\
\hline Penyajian & $\begin{array}{l}\text { Menjelaskan } \\
\text { Dinamika } \\
\text { interaksi } \\
\text { sosial dan } \\
\text { Dilema } \\
\text { kepentingan } \\
\text { individu dan } \\
\text { masyarakat }\end{array}$ & $\begin{array}{l}\text { Memperhatikan } \\
\text { dan diskusi. }\end{array}$ & 75 Menit & $\begin{array}{l}\text { Laptop, } \\
\text { LCD/Infocus dan } \\
\text { White board. }\end{array}$ \\
& $\begin{array}{l}\text { Menunjuk } \\
\text { beberapa } \\
\text { mahasiswa } \\
\text { secara acak } \\
\text { untuk } \\
\text { menjawab } \\
\text { pertanyaan. }\end{array}$ & $\begin{array}{l}\text { Menjawab } \\
\text { pertanyaan, } \\
\text { memberikan } \\
\text { pendapat dan } \\
\text { memperhatikan }\end{array}$ & 15 Menit & \\
& & & \\
& & & \\
\hline
\end{tabular}

E. EVALUASI : jelaskan dinamika interaksi sosial dan dilema kepentingan individu dan masyarakat 


\section{RENCANA PROGRAM PEMBELAJARAN}

(RPP)

$\begin{array}{ll}\text { Mata kuliah } & \text { : Ilmu Sosial Dasar } \\ \text { Kode Matakuliah } & : \text { MKK } 100107 \\ \text { sks } & : 2 \\ \text { Waktu pertemuan } & : 2 \times 50 \text { menit }\end{array}$

A. Tujuan

1. Standar Kompetensi

Mahasiswa dapat menjelaskan konsep-konsep social : dan budaya dasar

2. Kompetensi Dasar

: Menjelaskan hakikat manusia dan peradaban, serta dinamika peradaban global

B. Pokok Bahasan

: hakikat manusia dan peradaban, serta dinamika peradaban global

C. Sub Pokok Bahasan $\quad$ : Hakikat peradaban Mahluk beradab dan masyarakat beradab

D. Kegiatan Belajar Mengajar : Pertemuan ke 6 (Empat)

\begin{tabular}{|c|c|c|c|c|}
\hline $\begin{array}{c}\text { TAHAP } \\
\text { KEGIATAN }\end{array}$ & $\begin{array}{c}\text { KEGIATAN } \\
\text { DOSEN }\end{array}$ & $\begin{array}{l}\text { KEGIATAN } \\
\text { MAHASISWA }\end{array}$ & WAKTU & $\begin{array}{c}\text { MEDIA DAN } \\
\text { ALAT } \\
\text { PENGAJARAN }\end{array}$ \\
\hline Pendahuluan & $\begin{array}{l}\text { 1. Mengucapka } \\
\mathrm{n} \text { salam dan } \\
\text { menjelaskan } \\
\text { cakupan } \\
\text { materi } \\
\text { pertemuan } \\
\text { ke-6; } \\
\text { 2. Menjelaskan } \\
\text { manfaat } \\
\text { materi } \\
\text { pertemuan } \\
\text { ke-6; } \\
\text { 3. Relevansi } \\
\end{array}$ & $\begin{array}{l}\text { Memperhatikan } \\
\text { dan diskusi. }\end{array}$ & 10 Menit & $\begin{array}{l}\text { Laptop, } \\
\text { LCD/Infocus dan } \\
\text { White board. }\end{array}$ \\
\hline
\end{tabular}




\begin{tabular}{|c|c|c|c|c|}
\hline & $\begin{array}{l}\text { antara } \\
\text { standart } \\
\text { kompetensi } \\
\text { dengan } \\
\text { kompetensi } \\
\text { dasar. }\end{array}$ & & & \\
\hline Penyajian & $\begin{array}{l}\text { menjelaskan } \\
\text { Hakikat } \\
\text { peradaban } \\
\text { mahluk beradab } \\
\text { dan masyarakat } \\
\text { beradab }\end{array}$ & $\begin{array}{l}\text { Memperhatikan } \\
\text { dan diskusi. }\end{array}$ & 75 Menit & $\begin{array}{l}\text { Laptop, } \\
\text { LCD/Infocus dan } \\
\text { White board. }\end{array}$ \\
\hline Penutup & $\begin{array}{l}\text { Menunjuk } \\
\text { beberapa } \\
\text { mahasiswa } \\
\text { secara acak } \\
\text { untuk } \\
\text { menjawab } \\
\text { pertanyaan. }\end{array}$ & $\begin{array}{l}\text { Menjawab } \\
\text { pertanyaan, } \\
\text { memberikan } \\
\text { pendapat dan } \\
\text { memperhatikan }\end{array}$ & 15 Menit & \\
\hline
\end{tabular}

E. EVALUASI : jelaskan hakikat peradaban masyarakat beradab? 


\section{RENCANA PROGRAM PEMBELAJARAN}

(RPP)

$\begin{array}{ll}\text { Mata kuliah } & \text { : Ilmu Sosial Dasar } \\ \text { Kode Matakuliah } & : \text { MKK } 100107 \\ \text { sks } & : 2 \\ \text { Waktu pertemuan } & : 2 \times 50 \text { menit }\end{array}$

A. Tujuan

1. Standar Kompetensi Mahasiswa dapat menjelaskan konsep-konsep social : dan budaya dasar

2. Kompetensi Dasar

: Menjelaskan hakikat manusia dan peradaban, serta dinamika peradaban global

B. Pokok Bahasan

: hakikat manusia dan peradaban, serta dinamika peradaban global

C. Sub Pokok Bahasan $\quad$ : Evolusi budaya dan wujud peradaban Dinamika peradaban global serta Problematika peradaban

D. Kegiatan Belajar Mengajar : Pertemuan ke 7 (Tujuh)

\begin{tabular}{|c|c|c|c|c|}
\hline $\begin{array}{c}\text { TAHAP } \\
\text { KEGIATAN }\end{array}$ & $\begin{array}{c}\text { KEGIATAN } \\
\text { DOSEN }\end{array}$ & $\begin{array}{c}\text { KEGIATAN } \\
\text { MAHASISWA }\end{array}$ & WAKTU & $\begin{array}{c}\text { MEDIA DAN } \\
\text { ALAT } \\
\text { PENGAJARAN }\end{array}$ \\
\hline Pendahuluan & $\begin{array}{l}\text { 1. Mengucapka } \\
\text { n salam dan } \\
\text { menjelaskan } \\
\text { cakupan } \\
\text { materi } \\
\text { pertemuan } \\
\text { ke-7; } \\
\text { 2. Menjelaskan } \\
\text { manfaat } \\
\text { materi } \\
\text { pertemuan } \\
\text { ke-7; } \\
\text { 3. Relevansi } \\
\text { antara } \\
\text { standart } \\
\text { kompetensi }\end{array}$ & $\begin{array}{l}\text { Memperhatikan } \\
\text { dan diskusi. }\end{array}$ & 10 Menit & $\begin{array}{l}\text { Laptop, } \\
\text { LCD/Infocus dan } \\
\text { White board. }\end{array}$ \\
\hline
\end{tabular}




\begin{tabular}{|l|l|l|l|l|}
\hline & $\begin{array}{l}\text { dengan } \\
\text { kompetensi } \\
\text { dasar. }\end{array}$ & & \\
\hline Penyajian & $\begin{array}{l}\text { Menjelaskan } \\
\text { evolusi budaya } \\
\text { dan wujud } \\
\text { peradaban } \\
\text { serta diinamika } \\
\text { peradaban } \\
\text { global serta } \\
\text { Problematika } \\
\text { peradaban }\end{array}$ & $\begin{array}{l}\text { Memperhatikan } \\
\text { dan diskusi. }\end{array}$ & 75 Menit & $\begin{array}{l}\text { Laptop, } \\
\text { LCD/Infocus dan } \\
\text { White board. }\end{array}$ \\
\hline Penutup & $\begin{array}{l}\text { Menunjuk } \\
\text { beberapa } \\
\text { mahasiswa } \\
\text { secara acak } \\
\text { untuk } \\
\text { menjawab } \\
\text { pertanyaan. }\end{array}$ & $\begin{array}{l}\text { Menjawab } \\
\text { pertanyaan, } \\
\text { memberikan } \\
\text { pendapat dan } \\
\text { memperhatikan }\end{array}$ & 15 Menit & \\
& & & \\
\hline
\end{tabular}

E. EVALUASI : Jelaskan evolusi budaya dan wujud peradaban serta diinamika peradaban global serta Problematika peradaban 


\section{RENCANA PROGRAM PEMBELAJARAN}

(RPP)

$\begin{array}{ll}\text { Mata kuliah } & \text { : Ilmu Sosial Dasar } \\ \text { Kode Matakuliah } & : \text { MKK } 100107 \\ \text { sks } & : 2 \\ \text { Waktu pertemuan } & : 2 \times 50 \text { menit }\end{array}$

A. Tujuan

1. Standar Kompetensi

Mahasiswa dapat menjelaskan konsep-konsep social : dan budaya dasar

2. Kompetensi Dasar

: Menyebutkan hakikat keragaman dan kesetaraan dalam dinamika sosial manusia

B. Pokok Bahasan

: hakikat keragaman dan kesetaraan dalam dinamika sosial manusia

C. Sub Pokok Bahasan : Hakikat keragaman dan kesetaraanmanusia dan Kemajemukan dalam dinamika sosial budaya

D. Kegiatan Belajar Mengajar : Pertemuan ke 9 (sembilan)

\begin{tabular}{|c|c|c|c|c|}
\hline $\begin{array}{c}\text { TAHAP } \\
\text { KEGIATAN }\end{array}$ & $\begin{array}{c}\text { KEGIATAN } \\
\text { DOSEN }\end{array}$ & $\begin{array}{c}\text { KEGIATAN } \\
\text { MAHASISWA }\end{array}$ & WAKTU & $\begin{array}{c}\text { MEDIA DAN } \\
\text { ALAT } \\
\text { PENGAJARAN }\end{array}$ \\
\hline Pendahuluan & $\begin{array}{l}\text { 1. Mengucapkan } \\
\text { salam dan } \\
\text { menjelaskan } \\
\text { cakupan } \\
\text { materi } \\
\text { pertemuan ke- } \\
\text { 8; } \\
\text { 2. Menjelaskan } \\
\text { manfaat } \\
\text { materi } \\
\text { pertemuan ke- } \\
\text { 8; } \\
\text { 3. Relevansi } \\
\text { antara standart } \\
\text { kompetensi } \\
\text { dengan } \\
\text { kompetensi }\end{array}$ & $\begin{array}{l}\text { Memperhatikan } \\
\text { dan diskusi. }\end{array}$ & 10 Menit & $\begin{array}{l}\text { Laptop, } \\
\text { LCD/Infocus dan } \\
\text { White board. }\end{array}$ \\
\hline
\end{tabular}




\begin{tabular}{|c|c|c|c|c|}
\hline & dasar. & & & \\
\hline Penyajian & $\begin{array}{l}\text { 4. Menjelaskan } \\
\text { Hakikat } \\
\text { keragaman } \\
\text { dan } \\
\text { kesetaraanma } \\
\text { nusia dan } \\
\text { Kemajemukan } \\
\text { dalam } \\
\text { dinamika } \\
\text { sosial budaya }\end{array}$ & $\begin{array}{l}\text { Memperhatikan } \\
\text { dan diskusi. }\end{array}$ & 75 Menit & $\begin{array}{l}\text { Laptop, } \\
\text { LCD/Infocus dan } \\
\text { White board. }\end{array}$ \\
\hline Penutup & $\begin{array}{l}\text { 5. Menunjuk } \\
\text { beberapa } \\
\text { mahasiswa } \\
\text { secara acak } \\
\text { untuk } \\
\text { menjawab } \\
\text { pertanyaan. }\end{array}$ & $\begin{array}{l}\text { Menjawab } \\
\text { pertanyaan, } \\
\text { memberikan } \\
\text { pendapat dan } \\
\text { memperhatikan }\end{array}$ & 15 Menit & \\
\hline
\end{tabular}

E. EVALUASI : 1. Jelaskan Hakikat keragaman dan kesetaraan manusia?

2. Jelaskan kemajemukan dalam dinamika sosial budaya? 


\section{RENCANA PROGRAM PEMBELAJARAN}

(RPP)

$\begin{array}{ll}\text { Mata kuliah } & \text { : Ilmu Sosial Dasar } \\ \text { Kode Matakuliah } & : \text { MKK } 100107 \\ \text { sks } & : 2 \\ \text { Waktu pertemuan } & : 2 \times 50 \text { menit }\end{array}$

A. Tujuan

1. Standar Kompetensi

Mahasiswa dapat menjelaskan konsep-konsep social : dan budaya dasar

2. Kompetensi Dasar

: Menyebutkan hakikat keragaman dan kesetaraan dalam dinamika sosial manusia

B. Pokok Bahasan

: hakikat keragaman dan kesetaraan dalam dinamika sosial manusia

C. Sub Pokok Bahasan $\quad$ : Keragaman dan kesetaraan sebagai kekayaan sosial budaya Problematika keragaman dan kesetaraan

D. Kegiatan Belajar Mengajar : Pertemuan ke 10 (sepuluh)

\begin{tabular}{|c|c|c|c|c|}
\hline $\begin{array}{c}\text { TAHAP } \\
\text { KEGIATAN }\end{array}$ & $\begin{array}{l}\text { KEGIATAN } \\
\text { DOSEN }\end{array}$ & $\begin{array}{c}\text { KEGIATAN } \\
\text { MAHASISWA }\end{array}$ & WAKTU & $\begin{array}{c}\text { MEDIA } \\
\text { DAN ALAT } \\
\text { PENGAJAR } \\
\text { AN }\end{array}$ \\
\hline Pendahuluan & $\begin{array}{l}\text { 1. Mengucapkan } \\
\text { salam dan } \\
\text { menjelaskan } \\
\text { cakupan } \\
\text { materi } \\
\text { pertemuan ke- } \\
\text { 8; } \\
\text { 2. Menjelaskan } \\
\text { manfaat } \\
\text { materi } \\
\text { pertemuan ke- } \\
\text { 8; } \\
\text { 3. Relevansi } \\
\text { antara standart } \\
\text { kompetensi } \\
\text { dengan }\end{array}$ & $\begin{array}{l}\text { Memperhatikan } \\
\text { dan diskusi. }\end{array}$ & 10 Menit & $\begin{array}{l}\text { Laptop, } \\
\text { LCD/Infocus } \\
\text { dan White } \\
\text { board. }\end{array}$ \\
\hline
\end{tabular}




\begin{tabular}{|c|c|c|c|c|}
\hline & $\begin{array}{l}\text { kompetensi } \\
\text { dasar. }\end{array}$ & & & \\
\hline Penyajian & $\begin{array}{l}\text { 4. Menjelaskan } \\
\text { Keragaman } \\
\text { dan kesetaraan } \\
\text { sebagai } \\
\text { kekayaan } \\
\text { sosial budaya } \\
\text { Problematika } \\
\text { keragaman } \\
\text { dan kesetaraan }\end{array}$ & $\begin{array}{l}\text { Memperhatikan } \\
\text { dan diskusi. }\end{array}$ & 75 Menit & $\begin{array}{l}\text { Laptop, } \\
\text { LCD/Infocus } \\
\text { dan White } \\
\text { board. }\end{array}$ \\
\hline Penutup & $\begin{array}{l}\text { 5. Menunjuk } \\
\text { beberapa } \\
\text { mahasiswa } \\
\text { secara acak } \\
\text { untuk } \\
\text { menjawab } \\
\text { pertanyaan. }\end{array}$ & $\begin{array}{l}\text { Menjawab } \\
\text { pertanyaan, } \\
\text { memberikan } \\
\text { pendapat dan } \\
\text { memperhatikan }\end{array}$ & 15 Menit & \\
\hline
\end{tabular}

E. EVALUASI : 1. Jelaskan Keragaman dan kesetaraan sebagai kekayaan sosial budaya

2. Jelaskan Problematika keragaman dan kesetaraan 


\section{RENCANA PROGRAM PEMBELAJARAN}

(RPP)

$\begin{array}{ll}\text { Mata kuliah } & \text { : Ilmu Sosial Dasar } \\ \text { Kode Matakuliah } & : \text { MKK } 100107 \\ \text { sks } & : 2 \\ \text { Waktu pertemuan } & : 2 \times 50 \text { menit }\end{array}$

A. Tujuan

1. Standar Kompetensi

Mahasiswa dapat menjelaskan konsep-konsep social : dan budaya dasar

2. Kompetensi Dasar

: Merumuskan fungsi, nilai, moral, dan hukum dalam upaya mendapatkan keadilan, ketertiban dan kesejahteraan masyarakat

B. Pokok Bahasan

: hakikat, fungsi, nilai, moral, dan hukum dalam upaya mendapatkan keadilan, ketertiban dan kesejahteraan masyarakat

C. Sub Pokok Bahasan : Mengkaji hakikat, fungsi, nilai, moral dan hukum dan Mengkaji keadilan, ketertiban dan kesejahteraan

D. Kegiatan Belajar Mengajar : Pertemuan ke 11 (sebelas)

\begin{tabular}{|c|c|c|c|c|}
\hline $\begin{array}{c}\text { TAHAP } \\
\text { KEGIATAN }\end{array}$ & $\begin{array}{l}\text { KEGIATAN } \\
\text { DOSEN }\end{array}$ & $\begin{array}{c}\text { KEGIATAN } \\
\text { MAHASISWA }\end{array}$ & WAKTU & $\begin{array}{c}\text { MEDIA DAN } \\
\text { ALAT } \\
\text { PENGAJARAN }\end{array}$ \\
\hline Pendahuluan & $\begin{array}{l}\text { 1. Mengucapkan } \\
\text { salam dan } \\
\text { menjelaskan } \\
\text { cakupan } \\
\text { materi } \\
\text { pertemuan ke- } \\
8 \text {; } \\
\text { 2. Menjelaskan } \\
\text { manfaat } \\
\text { materi } \\
\text { pertemuan ke- } \\
\text { 8; }\end{array}$ & $\begin{array}{l}\text { Memperhatikan } \\
\text { dan diskusi. }\end{array}$ & 10 Menit & $\begin{array}{l}\text { Laptop, } \\
\text { LCD/Infocus dan } \\
\text { White board. }\end{array}$ \\
\hline
\end{tabular}




\begin{tabular}{|c|c|c|c|c|}
\hline & $\begin{array}{l}\text { 3. Relevansi } \\
\text { antara standart } \\
\text { kompetensi } \\
\text { dengan } \\
\text { kompetensi } \\
\text { dasar. }\end{array}$ & & & \\
\hline Penyajian & $\begin{array}{l}\text { 4. Menjelaskan i } \\
\text { hakikat, } \\
\text { fungsi, nilai, } \\
\text { moral dan } \\
\text { hukum dan } \\
\text { Mengkaji } \\
\text { keadilan, } \\
\text { ketertiban dan } \\
\text { kesejahteraan }\end{array}$ & $\begin{array}{l}\text { Memperhatikan } \\
\text { dan diskusi. }\end{array}$ & 75 Menit & $\begin{array}{l}\text { Laptop, } \\
\text { LCD/Infocus dan } \\
\text { White board. }\end{array}$ \\
\hline Penutup & $\begin{array}{l}\text { 5. Menunjuk } \\
\text { beberapa } \\
\text { mahasiswa } \\
\text { secara acak } \\
\text { untuk } \\
\text { menjawab } \\
\text { pertanyaan. }\end{array}$ & $\begin{array}{l}\text { Menjawab } \\
\text { pertanyaan, } \\
\text { memberikan } \\
\text { pendapat dan } \\
\text { memperhatikan }\end{array}$ & 15 Menit & \\
\hline
\end{tabular}

E. EVALUASI : Jelaskan Mengkaji hakikat, fungsi, nilai, moral dan hukum? 


\section{RENCANA PROGRAM PEMBELAJARAN}

(RPP)

$\begin{array}{ll}\text { Mata kuliah } & \text { : Ilmu Sosial Dasar } \\ \text { Kode Matakuliah } & : \text { MKK } 100107 \\ \text { sks } & : 2 \\ \text { Waktu pertemuan } & : 2 \times 50 \text { menit }\end{array}$

A. Tujuan

1. Standar Kompetensi

Mahasiswa dapat menjelaskan konsep-konsep social : dan budaya dasar

2. Kompetensi Dasar

: Merumuskan fungsi, nilai, moral, dan hukum dalam upaya mendapatkan keadilan, ketertiban dan kesejahteraan masyarakat

B. Pokok Bahasan

: hakikat, fungsi, nilai, moral, dan hukum dalam upaya mendapatkan keadilan, ketertiban dan kesejahteraan masyarakat

C. Sub Pokok Bahasan : Mengidentifikasi perwujudan masyarakat bermoral dan taat hukum serta problematika nilai, moral, dan hukum

D. Kegiatan Belajar Mengajar : Pertemuan ke 12 (duabelas)

\begin{tabular}{|c|c|c|c|c|}
\hline $\begin{array}{c}\text { TAHAP } \\
\text { KEGIATAN }\end{array}$ & $\begin{array}{l}\text { KEGIATAN } \\
\text { DOSEN }\end{array}$ & $\begin{array}{l}\text { KEGIATAN } \\
\text { MAHASISWA }\end{array}$ & WAKTU & $\begin{array}{c}\text { MEDIA DAN } \\
\text { ALAT } \\
\text { PENGAJARAN }\end{array}$ \\
\hline Pendahuluan & $\begin{array}{l}\text { 1. Mengucapkan } \\
\text { salam dan } \\
\text { menjelaskan } \\
\text { cakupan materi } \\
\text { pertemuan ke- } \\
8 \text {; } \\
\text { 2. Menjelaskan } \\
\text { manfaat materi } \\
\text { pertemuan ke- } \\
\text { 8; } \\
\text { 3. Relevansi } \\
\text { antara standart }\end{array}$ & $\begin{array}{l}\text { Memperhatikan } \\
\text { dan diskusi. }\end{array}$ & 10 Menit & $\begin{array}{l}\text { Laptop, } \\
\text { LCD/Infocus dan } \\
\text { White board. }\end{array}$ \\
\hline
\end{tabular}




\begin{tabular}{|c|c|c|c|c|}
\hline & $\begin{array}{l}\text { kompetensi } \\
\text { dengan } \\
\text { kompetensi } \\
\text { dasar. }\end{array}$ & & & \\
\hline Penyajian & $\begin{array}{l}\text { 4. Menjelaskan } \\
\text { perwujudan } \\
\text { masyarakat } \\
\text { bermoral dan } \\
\text { taat hukum } \\
\text { serta } \\
\text { problematika } \\
\text { nilai, moral, } \\
\text { dan hukum }\end{array}$ & $\begin{array}{l}\text { Memperhatikan } \\
\text { dan diskusi. }\end{array}$ & 75 Menit & $\begin{array}{l}\text { Laptop, } \\
\text { LCD/Infocus dan } \\
\text { White board. }\end{array}$ \\
\hline Penutup & $\begin{array}{l}\text { 5. Menunjuk } \\
\text { beberapa } \\
\text { mahasiswa } \\
\text { secara acak } \\
\text { untuk } \\
\text { menjawab } \\
\text { pertanyaan. }\end{array}$ & $\begin{array}{l}\text { Menjawab } \\
\text { pertanyaan, } \\
\text { memberikan } \\
\text { pendapat dan } \\
\text { memperhatikan }\end{array}$ & 15 Menit & \\
\hline
\end{tabular}

E. EVALUASI : Jelaskan perwujudan masyarakat bermoral dan taat 


\title{
RENCANA PROGRAM PEMBELAJARAN
}

(RPP)

\author{
Mata kuliah : Ilmu Sosial Dasar \\ Kode Matakuliah : : MKK 100107 \\ sks $\quad: 2$
}

Waktu pertemuan $\quad: 2 \times 50$ menit
A. Tujuan
1. Standar Kompetensi
Mahasiswa dapat menjelaskan konsep-konsep social
: dan budaya dasar
2. Kompetensi Dasar
: Menguraikan hakikat dan makna sains, teknologi, dan seni, dan dampak dan pemanfaatan teknologi di Indonesia
B. Pokok Bahasan
: hakikat dan makna sains, teknologi, dan seni, dan dampak dan pemanfaatan teknologi di Indonesia
C. Sub Pokok Bahasan : Hakikat dan makna sains, teknologi, dan seni bagi manusia
Dampak penyalahgunaan IPTEKS pada kehidupan sosbud serta Problematika pemanfaatan IPTEKS di Indonesia

D. Kegiatan Belajar Mengajar : Pertemuan ke 13 (tiga belas)

\begin{tabular}{|c|c|c|c|c|}
\hline $\begin{array}{c}\text { TAHAP } \\
\text { KEGIATAN }\end{array}$ & $\begin{array}{c}\text { KEGIATAN } \\
\text { DOSEN }\end{array}$ & $\begin{array}{c}\text { KEGIATAN } \\
\text { MAHASISWA }\end{array}$ & WAKTU & $\begin{array}{c}\text { MEDIA DAN } \\
\text { ALAT } \\
\text { PENGAJARAN }\end{array}$ \\
\hline Pendahuluan & $\begin{array}{l}\text { 1. Mengucapkan } \\
\text { salam dan } \\
\text { menjelaskan } \\
\text { cakupan } \\
\text { materi } \\
\text { pertemuan ke- } \\
8 \text {; } \\
\text { 2. Menjelaskan } \\
\text { manfaat } \\
\text { materi } \\
\text { pertemuan ke- } \\
\text { 8; } \\
\text { 3. Relevansi }\end{array}$ & $\begin{array}{l}\text { Memperhatikan } \\
\text { dan diskusi. }\end{array}$ & 10 Menit & $\begin{array}{l}\text { Laptop, } \\
\text { LCD/Infocus dan } \\
\text { White board. }\end{array}$ \\
\hline
\end{tabular}




\begin{tabular}{|c|c|c|c|c|}
\hline & $\begin{array}{l}\text { antara standart } \\
\text { kompetensi } \\
\text { dengan } \\
\text { kompetensi } \\
\text { dasar. }\end{array}$ & & & \\
\hline Penyajian & $\begin{array}{l}\text { 4. Menjelaskan } \\
\text { dampak } \\
\text { penyalahguna } \\
\text { an IPTEKS } \\
\text { pada } \\
\text { kehidupan } \\
\text { sosbud serta } \\
\text { Problematika } \\
\text { pemanfaatan } \\
\text { IPTEKS di } \\
\text { Indonesia }\end{array}$ & $\begin{array}{l}\text { Memperhatikan } \\
\text { dan diskusi. }\end{array}$ & 75 Menit & $\begin{array}{l}\text { Laptop, } \\
\text { LCD/Infocus dan } \\
\text { White board. }\end{array}$ \\
\hline Penutup & $\begin{array}{l}\text { 5. Menunjuk } \\
\text { beberapa } \\
\text { mahasiswa } \\
\text { secara acak } \\
\text { untuk } \\
\text { menjawab } \\
\text { pertanyaan. }\end{array}$ & $\begin{array}{l}\text { Menjawab } \\
\text { pertanyaan, } \\
\text { memberikan } \\
\text { pendapat dan } \\
\text { memperhatikan }\end{array}$ & 15 Menit & \\
\hline
\end{tabular}

E. EVALUASI : Jelaskan dampak penyalahgunaan IPTEKS pada kehidupan 


\title{
RENCANA PROGRAM PEMBELAJARAN
}

(RPP)

\author{
Mata kuliah : Ilmu Sosial Dasar \\ Kode Matakuliah : : MKK 100107 \\ sks $\quad: 2$
}

Waktu pertemuan $\quad: 2 \times 50$ menit
A. Tujuan
1. Standar Kompetensi
Mahasiswa dapat menjelaskan konsep-konsep
: social dan budaya dasar
2. Kompetensi Dasar
: Menjelaskan hakikat dan makna lingkungan bagi kesejahteraan
B. Pokok Bahasan : hakikat dan makna lingkungan bagi kesejahteraan
C. Sub Pokok Bahasan : Hakikat dan makna lingkungan bagi manusia dan Kualitas penduduk dan lingkungan terhadap kesejahteraan

D. Kegiatan Belajar Mengajar : Pertemuan ke 14 (empat belas)

\begin{tabular}{|c|c|c|c|c|}
\hline $\begin{array}{c}\text { TAHAP } \\
\text { KEGIATAN }\end{array}$ & $\begin{array}{c}\text { KEGIATAN } \\
\text { DOSEN }\end{array}$ & $\begin{array}{l}\text { KEGIATAN } \\
\text { MAHASISWA }\end{array}$ & WAKTU & $\begin{array}{c}\text { MEDIA DAN } \\
\text { ALAT } \\
\text { PENGAJARAN }\end{array}$ \\
\hline Pendahuluan & $\begin{array}{l}\text { 1. Mengucapkan } \\
\text { salam dan } \\
\text { menjelaskan } \\
\text { cakupan } \\
\text { materi } \\
\text { pertemuan ke- } \\
8 \text {; } \\
\text { 2. Menjelaskan } \\
\text { manfaat } \\
\text { materi } \\
\text { pertemuan ke- } \\
\text { 8; } \\
\text { 3. Relevansi } \\
\text { antara standart } \\
\text { kompetensi } \\
\text { dengan } \\
\text { kompetensi }\end{array}$ & $\begin{array}{l}\text { Memperhatikan } \\
\text { dan diskusi. }\end{array}$ & 10 Menit & $\begin{array}{l}\text { Laptop, } \\
\text { LCD/Infocus dan } \\
\text { White board. }\end{array}$ \\
\hline
\end{tabular}




\begin{tabular}{|c|c|c|c|c|}
\hline & dasar. & & & \\
\hline Penyajian & $\begin{array}{l}\text { 4. Menjelaskan } \\
\text { Hakikat dan } \\
\text { makna } \\
\text { lingkungan } \\
\text { bagi manusia } \\
\text { dan Kualitas } \\
\text { penduduk dan } \\
\text { lingkungan } \\
\text { terhadap } \\
\text { kesejahteraan }\end{array}$ & $\begin{array}{l}\text { Memperhatikan } \\
\text { dan diskusi. }\end{array}$ & 75 Menit & $\begin{array}{l}\text { Laptop, } \\
\text { LCD/Infocus dan } \\
\text { White board. }\end{array}$ \\
\hline Penutup & $\begin{array}{l}\text { 5. Menunjuk } \\
\text { beberapa } \\
\text { mahasiswa } \\
\text { secara acak } \\
\text { untuk } \\
\text { menjawab } \\
\text { pertanyaan. }\end{array}$ & $\begin{array}{l}\text { Menjawab } \\
\text { pertanyaan, } \\
\text { memberikan } \\
\text { pendapat dan } \\
\text { memperhatikan }\end{array}$ & 15 Menit & \\
\hline
\end{tabular}

E. EVALUASI : Jelaskan dan Kualitas penduduk dan lingkungan terhadap kesejahteraan 


\section{RENCANA PROGRAM PEMBELAJARAN}

(RPP)
Mata kuliah
: Ilmu Sosial Dasar
Kode Matakuliah
: MKK 100107
sks
$: 2$
Waktu pertemuan
: 2 x 50 menit
D. Tujuan
1. Standar Kompetensi
Mahasiswa dapat menjelaskan konsep-konsep social : dan budaya dasar
2. Kompetensi Dasar
: Menguraikan hakikat dan makna lingkungan bagi kesejahteraan
E. Pokok Bahasan
: hakikat dan makna lingkungan bagi kesejahteraan
F. Sub Pokok Bahasan
: Problema lingkungan sosial budaya dan Isu-isu penting tentang lintas budaya dan bangsa

D. Kegiatan Belajar Mengajar : Pertemuan ke 15 (lima belas)

\begin{tabular}{|c|c|c|c|c|}
\hline $\begin{array}{c}\text { TAHAP } \\
\text { KEGIATAN }\end{array}$ & $\begin{array}{c}\text { KEGIATAN } \\
\text { DOSEN }\end{array}$ & $\begin{array}{c}\text { KEGIATAN } \\
\text { MAHASISWA }\end{array}$ & WAKTU & $\begin{array}{c}\text { MEDIA DAN } \\
\text { ALAT } \\
\text { PENGAJARAN }\end{array}$ \\
\hline Pendahuluan & $\begin{array}{l}\text { 1. Mengucapkan } \\
\text { salam dan } \\
\text { menjelaskan } \\
\text { cakupan materi } \\
\text { pertemuan ke- } \\
8 \text {; } \\
\text { 2. Menjelaskan } \\
\text { manfaat materi } \\
\text { pertemuan ke- } \\
\text { 8; } \\
\text { 3. Relevansi } \\
\text { antara standart } \\
\text { kompetensi } \\
\text { dengan } \\
\text { kompetensi } \\
\text { dasar. }\end{array}$ & $\begin{array}{l}\text { Memperhatikan } \\
\text { dan diskusi. }\end{array}$ & 10 Menit & $\begin{array}{l}\text { Laptop, } \\
\text { LCD/Infocus dan } \\
\text { White board. }\end{array}$ \\
\hline Penyajian & $\begin{array}{l}\text { 4. Menjelaskan } \\
\text { Problema } \\
\text { lingkungan } \\
\text { sosial budaya } \\
\text { dan Isu-isu }\end{array}$ & $\begin{array}{l}\text { Memperhatikan } \\
\text { dan diskusi. }\end{array}$ & 75 Menit & $\begin{array}{l}\text { Laptop, } \\
\text { LCD/Infocus dan } \\
\text { White board. }\end{array}$ \\
\hline
\end{tabular}




\begin{tabular}{|l|l|l|l|l|}
\hline & $\begin{array}{l}\text { penting tentang } \\
\text { lintas budaya } \\
\text { dan bangsa }\end{array}$ & & \\
\hline Penutup & $\begin{array}{l}\text { 5. Menunjuk } \\
\text { beberapa } \\
\text { mahasiswa } \\
\text { secara acak } \\
\text { untuk } \\
\text { menjawab } \\
\text { pertanyaan. }\end{array}$ & $\begin{array}{l}\text { Menjawab } \\
\text { pertanyaan, } \\
\text { memberikan } \\
\text { pendapat dan } \\
\text { memperhatikan }\end{array}$ & & \\
& & & \\
& & & \\
\hline
\end{tabular}

E. EVALUASI : 1. Jelaskan problema lingkungan sosial budaya

2. Jelaskan dan Isu-isu penting tentang lintas budaya dan bangsa 


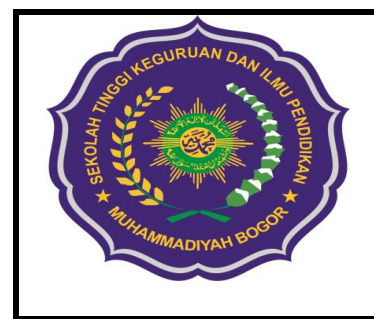

KONTRAK PERKULIAHAN

Kode MK : MKK 100107

Jml SKS : 2

Nama MK : Ilmu Sosial Dasar

Tg IBerlaku :

\section{A. Identitas}

\begin{tabular}{|l|l|}
\hline $\begin{array}{l}\text { Objective [ TIU ] } \\
\text { (STANDAR } \\
\text { KOMPETENSI) }\end{array}$ & 1 x 100 menit tatap muka, \\
\hline $\begin{array}{l}\text { Jml Jam kuliah } \\
\text { dalam seminggu }\end{array}$ & x. 100 menit persiapan dan pekerjaan di luar kelas \\
\hline $\begin{array}{l}\text { Jml Jam kegiatan } \\
\text { laboratorium }\end{array}$ & Nama : Wahyu Bagja Sulfemi, SS. \\
\hline Dosen Penyusun & \\
\hline
\end{tabular}

\section{B. Level Taksonomi}

\begin{tabular}{|l|l|l|}
\hline Kspek & Koginitf & $\sqrt{ }$ \\
\cline { 2 - 3 } & Comprehension & $\sqrt{ }$ \\
\hline & Application & \\
\cline { 2 - 3 } & Analysis & \\
\hline & Synthesis & \\
\hline & Evaluation & \\
\hline \multirow{4}{*}{ Pspek } & Perception & \\
\hline & Preparation & \\
\hline & Mechanization & \\
\hline & Motorization & \\
\hline & Creativity & \\
\hline
\end{tabular}

\begin{tabular}{|l|l|l|}
\hline $\begin{array}{l}\text { Aspek } \\
\text { Afektif }\end{array}$ & $\begin{array}{l}\text { Receiving } \\
\text { Phenomena }\end{array}$ & \\
\hline & $\begin{array}{l}\text { Responding to } \\
\text { Phenomena }\end{array}$ & \\
\hline & Valuing & $\sqrt{ }$ \\
\hline & Organization & \\
\hline & Characterization & \\
\cline { 2 - 3 } & & \\
\hline
\end{tabular}

C. Keterampilan Profesi (PersyaratanBisnis / Industri)

\begin{tabular}{|l|l|}
\hline Aspek & $\begin{array}{l}\text { Kemampuan } \\
\text { Ketrampilan }\end{array}$ \\
\hline Menulis & $15 \%$ \\
\hline Bertanya & $10 \%$ \\
\hline Presentasi \& Diskusi & $50 \%$ \\
\hline $\begin{array}{l}\text { Komunikasi \& kerjasama dalam } \\
\text { Tim }\end{array}$ & $15 \%$ \\
\hline Keputusan & $10 \%$ \\
\hline
\end{tabular}

D. Materi dan Pelaksanaan

\begin{tabular}{|l|l|l|}
\hline Pertemuan & Sub Pokok Bahasan & Materi Bahasan \\
\hline
\end{tabular}




\begin{tabular}{|c|c|c|}
\hline Ke & & \\
\hline 1 & $\begin{array}{l}\text { Hakikat dan ruang lingkup } \\
\text { ISD, dan ISD sebagai } \\
\text { alternatif solusi problem sosbu }\end{array}$ & $\begin{array}{l}\text { 1. Hakikat dan ruang } \\
\text { lingkup ISD } \\
\text { 2. ISD sebagai alternatif } \\
\text { solusi problem social } \\
\text { budaya }\end{array}$ \\
\hline 2 & $\begin{array}{l}\text { Hakikat manusia sebagai } \\
\text { mahluk budaya dan Apresiasi } \\
\text { kemanusiaan dan kebudayaan }\end{array}$ & $\begin{array}{l}\text { 1. Hakikat manusia } \\
\text { 2. Pengertian kebudayaan } \\
\text { 3. Hakikat manusia } \\
\text { 4. sebagai mahluk budaya } \\
\text { 5. Apresiasi kemanusiaan } \\
\text { dan kebudayaan }\end{array}$ \\
\hline 3 & $\begin{array}{l}\text { Etika dan Estetika budaya, } \\
\text { Konsep-konsep dasar manusia } \\
\text { dan Problema kebudayaan }\end{array}$ & $\begin{array}{l}\text { 1. Pengertian Etika dan } \\
\text { Estetika } \\
\text { 2. Konsep-konsep dasar } \\
\text { manusia } \\
\text { 3. Problema kebudayaan } \\
\end{array}$ \\
\hline 4 & $\begin{array}{l}\text { Hakikat manusia sebagai } \\
\text { individu dan mahluk sosial dan } \\
\text { Fungsi dan peran manusia } \\
\text { sebagai individu dan mahluk } \\
\text { sosial }\end{array}$ & $\begin{array}{l}\text { 1. Pengertian individu dan } \\
\text { 2. individu mahluk sosial } \\
\text { 3. Fungsi dan peran manusia } \\
\text { sebagai individu dan } \\
\text { mahluk sosial }\end{array}$ \\
\hline 5 & $\begin{array}{l}\text { Dinamika interaksi sosial dan } \\
\text { Dilema kepentingan individu } \\
\text { dan masyarakat }\end{array}$ & $\begin{array}{l}\text { 1. interaksi sosial } \\
\text { 2. Dinamika interaksi sosial } \\
\text { 3. Pengertian Masyarakat } \\
\text { 4. Dilema kepentingan } \\
\text { individu dan masyarakat } \\
\end{array}$ \\
\hline 6 & $\begin{array}{l}\text { Hakikat peradaban Mahluk } \\
\text { beradab dan masyarakat } \\
\text { beradab }\end{array}$ & $\begin{array}{l}\text { 1. Hakikat peradaban } \\
\text { 2. Mahluk beradab dan } \\
\text { 3. masyarakat beradab } \\
\text { 4. Mahluk beradab da } \\
\text { masyarakat beradab }\end{array}$ \\
\hline 7 & $\begin{array}{l}\text { Evolusi budaya dan wujud } \\
\text { peradaban Dinamika peradaban } \\
\text { global serta Problematika } \\
\text { peradaban }\end{array}$ & $\begin{array}{l}\text { 1. Evolusi budaya dan wujud } \\
\text { peradaban } \\
\text { 2. Dinamika peradaban } \\
\text { global } \\
\text { 3. Problematika peradaban }\end{array}$ \\
\hline 8 & $\begin{array}{ll}\text { UJIAN } & \text { TENGAH } \\
\text { SEMESTER } & \end{array}$ & \\
\hline 9 & $\begin{array}{l}\text { Hakikat keragaman dan } \\
\text { kesetaraanmanusia dan } \\
\text { Kemajemukan dalam dinamika } \\
\text { sosial budaya }\end{array}$ & $\begin{array}{l}\text { 1. Hakikat keragaman } \\
\text { 2. kesetaraanmanusia } \\
\text { 3. Kemajemukan dalam } \\
\text { dinamika sosial budaya }\end{array}$ \\
\hline 10 & $\begin{array}{l}\text { Keragaman dan kesetaraan } \\
\text { sebagai kekayaan sosial }\end{array}$ & $\begin{array}{l}\text { 1. Keragaman dan kesetaraan } \\
\text { sebagai kekayaan sosial }\end{array}$ \\
\hline
\end{tabular}




\begin{tabular}{|c|c|c|}
\hline & $\begin{array}{l}\text { budaya Problematika } \\
\text { keragaman dan kesetaraan }\end{array}$ & $\begin{array}{l}\text { budaya } \\
\text { 2. Problematika keragaman } \\
\text { dan kesetaraan }\end{array}$ \\
\hline 11 & $\begin{array}{l}\text { Mengkaji hakikat, fungsi, nilai, } \\
\text { moral dan hukum dan } \\
\text { Mengkaji keadilan, ketertiban } \\
\text { dan kesejahteraan }\end{array}$ & $\begin{array}{l}\text { 1. Hakikat fungsi } \\
\text { 2. Hakikat nilai } \\
\text { 3. Hakikat moral dan hukum } \\
\text { 4. Pengertian Keadilan, } \\
\text { 5. Pengertian ketertiban dan } \\
\text { kesejahteraan }\end{array}$ \\
\hline 12 & $\begin{array}{l}\text { Mengidentifikasi perwujudan } \\
\text { masyarakat bermoral dan taat } \\
\text { hukum serta problematika } \\
\text { nilai, moral, dan hukum }\end{array}$ & $\begin{array}{l}\text { 1. Perwujudan masyarakat } \\
\text { bermoral } \\
\text { 2. Perwujudan masyarakat } \\
\text { taat hukum } \\
\text { 3. Problematika nilai, dan } \\
\text { moral } \\
\text { 4. Problematika hukum }\end{array}$ \\
\hline 13 & $\begin{array}{l}\text { Hakikat dan makna sains, } \\
\text { teknologi, dan seni bagi } \\
\text { manusia serta Dampak } \\
\text { penyalahgunaan IPTEKS pada } \\
\text { kehidupan sosbud serta } \\
\text { Problematika pemanfaatan } \\
\text { IPTEKS di Indonesia }\end{array}$ & $\begin{array}{l}\text { 1. Hakikat makna sains, } \\
\text { 2. Hakikat teknologi } \\
\text { 3. Hakikat dan seni bagi } \\
\text { manusia } \\
\text { 4. Dampak penyalahgunaan } \\
\text { IPTEKS pada kehidupan } \\
\text { sosbud } \\
\text { 5. Problematika pemanfaatan } \\
\text { IPTEKS di Indonesia } \\
\end{array}$ \\
\hline 14 & $\begin{array}{l}\text { Hakikat dan makna lingkungan } \\
\text { bagi manusia dan Kualitas } \\
\text { penduduk dan lingkungan } \\
\text { terhadap kesejahteraan }\end{array}$ & $\begin{array}{ll}\text { 1. } & \text { Hakikat dan makna } \\
\text { lingkungan bagi manusia } \\
\text { 2. } \\
\text { Kualitas penduduk dan } \\
\text { lingkungan terhadap } \\
\text { kesejahteraan }\end{array}$ \\
\hline 15 & \begin{tabular}{llrr} 
Problema & \multicolumn{2}{l}{ lingkungan } & sosial \\
budaya & dan & Isu-isu & penting \\
tentang & lintas & budaya & dan \\
bangsa & & &
\end{tabular} & $\begin{array}{l}\text { 1. Problema lingkungan } \\
\text { sosial budaya } \\
\text { 2. Isu-isu penting tentang } \\
\text { lintas budaya dan bangsa }\end{array}$ \\
\hline 16 & UJIAN AKHIR SEMESTER & \\
\hline
\end{tabular}

\section{E. Metode Penyampaian Materi/Sistem Perkuliahan}

1. Ceramah dan tanya jawab;

2. Presentasi dan diskusi

3. Penugasan;

\section{F. Rencana Tugas Mandiri}

\begin{tabular}{|l|l|l|}
\hline Tugas Ke & Jenis *) & Isi Tugas \\
\hline Kesatu & Individu & $\begin{array}{l}\text { Menjelaskan ISD sebagai alternatif solusi problem } \\
\text { social budaya }\end{array}$ \\
\hline
\end{tabular}




\begin{tabular}{|c|c|c|}
\hline Kedua & Individu & Menjelaskan manusia sebagai mahluk budaya \\
\hline Ketiga & Individu & $\begin{array}{l}\text { Makalah Etika dan Estetika budaya, Konsep-konsep } \\
\text { dasar manusia dan Problema kebudayaan }\end{array}$ \\
\hline Keempat & Individu & $\begin{array}{l}\text { Menjelaskan Hakikat manusia sebagai individu dan } \\
\text { mahluk sosial dan Fungsi dan peran manusia sebagai } \\
\text { individu dan mahluk sosial }\end{array}$ \\
\hline Kelima & Individu & $\begin{array}{l}\text { Menjelaskan Dinamika interaksi sosial dan Dilema } \\
\text { kepentingan individu dan masyarakat }\end{array}$ \\
\hline Keenam & Individu & $\begin{array}{l}\text { Menjelaskan Hakikat peradaban Mahluk beradab dan } \\
\text { masyarakat beradab }\end{array}$ \\
\hline Ketujuh & Individu & $\begin{array}{l}\text { Menjelaskan Evolusi budaya dan wujud peradaban } \\
\begin{array}{l}\text { Dinamika peradaban global serta Problematika } \\
\text { peradaban }\end{array}\end{array}$ \\
\hline Kedelapan & Ujian Ten & Semester(UTS) \\
\hline Kesembilan & Individu & $\begin{array}{l}\text { Menjelaskan Hakikat keragaman, kesetaraanmanusia } \\
\text { dan Kemajemukan dalam dinamika sosial }\end{array}$ \\
\hline Kesepuluh & Kelompok & $\begin{array}{l}\text { Menjelaskan Mengkaji hakikat, fungsi, nilai, moral } \\
\text { dan hukum dan Mengkaji keadilan, ketertiban dan } \\
\text { kesejahteraan }\end{array}$ \\
\hline Kesebelas & Individu & $\begin{array}{l}\text { Menjelaskan Mengidentifikasi perwujudan } \\
\text { masyarakat bermoral dan taat hukum serta } \\
\text { problematika nilai, moral, dan hukum }\end{array}$ \\
\hline Keduabelas & Kelompok & $\begin{array}{l}\text { Menjelaskan Hakikat dan makna sains, teknologi, dan } \\
\text { seni bagi manusia }\end{array}$ \\
\hline Ketigabelas & Kelompok & $\begin{array}{l}\text { Menjelaskan Dampak penyalahgunaan IPTEKS pada } \\
\text { kehidupan sosbud serta Problematika pemanfaatan } \\
\text { IPTEKS di Indonesia }\end{array}$ \\
\hline Keempatbelas & Kelompok & $\begin{array}{l}\text { Menjelaskan Hakikat dan makna lingkungan bagi } \\
\text { manusia dan Kualitas penduduk dan lingkungan } \\
\text { terhadap kesejahteraan }\end{array}$ \\
\hline Kelimabelas & Individu & $\begin{array}{l}\text { Menjelaskan Problema lingkungan sosial budaya dan } \\
\text { Isu-isu penting tentang lintas budaya dan bangsa }\end{array}$ \\
\hline Keenambelas & \multicolumn{2}{|c|}{ Ujian Akhir Semester(UAS) } \\
\hline
\end{tabular}

*) Diisi : kelompok / individ

\section{H. Rencana Ujian}

1. UJIAN TENGAH SEMESTER

2. UJIAN AKHIR SEMESTER

3. Ketentuan Ujian :

Mahasiswa dapat mengikuti ujian dengan kehadiran dalam kuliah minimal $75 \%$

\section{Penilaian}




\begin{tabular}{|l|c|c|}
\hline Aspek Penilaian & Komposisi Penilaian & Prosentase \\
\hline Kehadiran & $10 \%$ & $5-15 \%$ \\
\hline Tugas Mandiri & $10 \%$ & $5-15 \%$ \\
\hline Tugaskelompok & $10 \%$ & $5-15 \%$ \\
\hline Hasil UTS & $30 \%$ & $5-50 \%$ \\
\hline Hasil UAS & $40 \%$ & $5-50 \%$ \\
\hline & Total : & $\mathbf{1 0 0} \%$ \\
\hline
\end{tabular}




\section{RANCANGAN TUGAS PEMBELAJARAN \\ PROGRAM STUDI TEKNIK INFORMATIKA \\ TAHUN AKADEMIK2007 - 2014}

\begin{tabular}{|c|c|}
\hline MATA KULIAH & Ilmu Sosial Dasar \\
\hline KODE MATA KULIAH & MKK 100107 \\
\hline S K S & 2 \\
\hline $\begin{array}{l}\text { PENANGGUNG JAWAB } \\
\text { MK. }\end{array}$ & Wahyu Bagja Sulfemi, SS. \\
\hline DESKRIPSI SINGKAT & $\begin{array}{l}\text { Mata kuliah Ilmu Sosial Dasaradalah salah satu dari } \\
\text { mata kuliah kelompok Matakuliah Berkehidupan } \\
\text { Bermasyarakat (MBB) di perguruan tinggi. } \\
\text { Matakuliah ISD mengetengahkan pengetahuan dasar } \\
\text { tentang konsep-konsep manusia, konsep-konsep } \\
\text { kebudayaan, konsep-konsep sosiologi, konsep- } \\
\text { konsep nilai, moral, dan hukum, dan konsep-konsep } \\
\text { sains, teknoloi, seni, dan lingkungan }\end{array}$ \\
\hline STANDAR KOMPETENSI & $\begin{array}{l}\text { Setelah mengikuti matakuliah ini mahasiswa dapat } \\
\text { menjelaskan konsep-konsep social dan budaya dasar }\end{array}$ \\
\hline
\end{tabular}

DESKRIPSI TUGAS - 1

1. TUJUAN TUGAS : Mahasiswa dapat Menjelaskan dan Merumuskan manusia sebagai mahluk berbudaya, beretika, dan berestetika Merumuskan dan mengespresikan manusia sebagai mahluk berbudaya, beretika, dan berestetika.

2. URAIAN TUGAS : Membuat laporan berupa penjelasan berbagai budaya dari beberapa daerah

3. KRITERIA

: Penilaian dilakukan berdasarkan lembar kerja yang dibuat PENILAIAN dan diserahkan berdasarkan hasil pemahaman mahasiswa.

\section{DESKRIPSI TUGAS -2}

1. TUJUAN TUGAS : Mahasiswa dapat mendefinisikan hakikat manusia sebagai individu dan mahluk sosial

2. URAIAN TUGAS : Berupa tes uraian dari dosen mengenai definisi indivu dan mahluk sosial

3. KRITERIA : Penilaian dilakukan berdasarkan lembar kerja yang dibuat PENILAIAN 
dan diserahkan berdasarkan hasil pemahaman mahasiswa.

DESKRIPSI TUGAS $-\mathbf{3}$

1. TUJUAN TUGAS : Mahasiswa mampu menjelaskan manusia dan peradaban, dan dinamika peradaban global

2. URAIAN TUGAS : Menjelaskan manusia dan peradaban, dan dinamika peradaban global

3. KRITERIA : Penilaian dilakukan berdasarkan lembar kerja yang dibuat PENILAIAN dan diserahkan berdasarkan hasil pemahaman mahasiswa.

\section{DESKRIPSI TUGAS -4}

1. TUJUAN TUGAS : Mahasiswa dapat menyebutkan hakikat keragaman dan kesetaraan dalam dinamika sosial manusia ।

2. URAIAN TUGAS : Membuat makalah.

3. KRITERIA : Penilaian dilakukan berdasarkan lembar kerja yang dibuat PENILAIAN dan diserahkan berdasarkan hasil pemahaman mahasiswa.

\section{DESKRIPSI TUGAS - 5}

1. TUJUAN TUGAS : Mahasiswa dapat merumuskan hakikat, fungsi, nilai, moral, dan hukum dalam upaya mendapatkan keadilan, ketertiban dan kesejahteraan masyarakat

2. URAIAN TUGAS : Merumuskan hakikat, fungsi, nilai, moral, dan hukum dalam upaya mendapatkan keadilan, ketertiban dan kesejahteraan masyarakat dari berbagai sumber dengan diberikan tugas esay

3. KRITERIA

: Penilaian dilakukan berdasarkan lembar kerja yang dibuat PENILAIAN dan diserahkan berdasarkan hasil pemahaman mahasiswa.

\section{DESKRIPSI TUGAS - 6}

1. TUJUAN TUGAS : Mahasiswa mampu menguraikan hakikat dan makna sains, teknologi, dan seni, dan dampak dan pemanfaatan teknologi di Indonesia 
2. URAIAN TUGAS : Berupa tes uraian yang diberikan mengenai sains, teknologi, dan seni, dan dampak dan pemanfaatan teknologi di Indonesia

3. KRITERIA

: Penilaian dilakukan berdasarkan lembar kerja yang dibuat PENILAIAN dan diserahkan berdasarkan hasil pemahaman mahasiswa.

DESKRIPSI TUGAS -7

1. TUJUAN TUGAS : Mahasiswa mampu menguraian hakikat dan makna lingkungan bagi kesejahteraan

2. URAIAN TUGAS : Membuat makalah mengenai lingkungan hidup

3. KRITERIA : Penilaian dilakukan berdasarkan laporan kerja yang PENILAIAN dibuat secara kelompok. 
RENCANA EVALUASI

PROSES PEMBELAJARAN

Mata Kuliah

Kode Mata

Kuliah/SKS/Semester

Program Studi

Waktu Pelaksanaan

Tujuan Evaluasi
: ILMU SOSIAL DASAR

: MKK 005/2SKS/2

: ADMINISTRASI PENDIDIKAN

: UJIAN TENGAH SEMESTER DAN UJIAN AKHIR SEMESTER

: 1. Mengukur persepsi mahasiswa terhadap kemampuan dosen dalam menyelenggarakan kegiatan pembelajaran;

2. Mengukur persepsi mahasiswa terhadap kualitas materi perkuliahan;

3. Mengukur persepsi mahasiswa terhadap sarana pendukung pelaksanaan perkuliahan;

4. Mencari masukan dari mahasiswa tentang masalah yang biasa muncul dalam mengikuti kegiatan pembelajaran. 
TABEL 1

RENCANA EVALUASI PROSES BELAJAR MENGAJAR

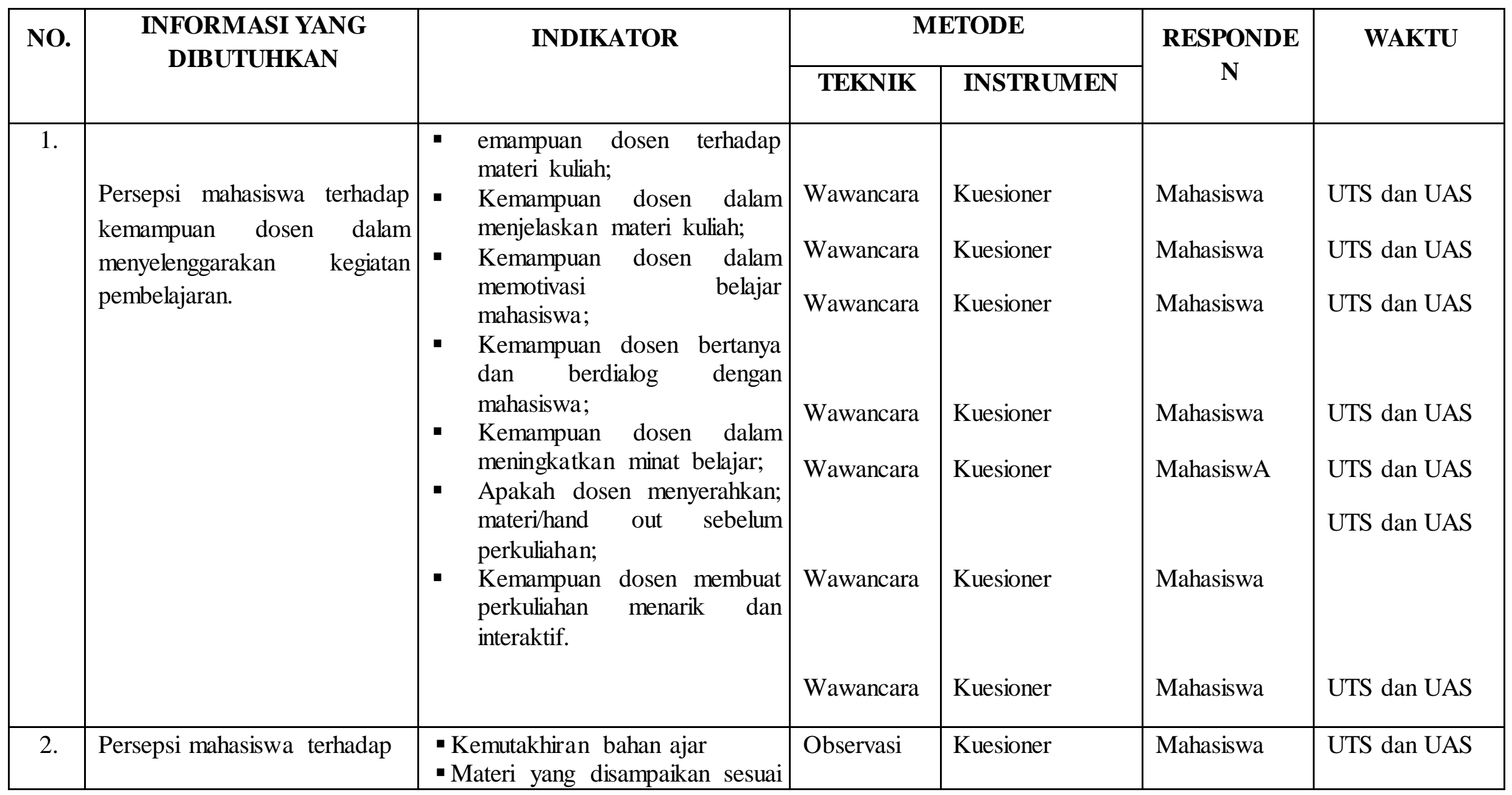




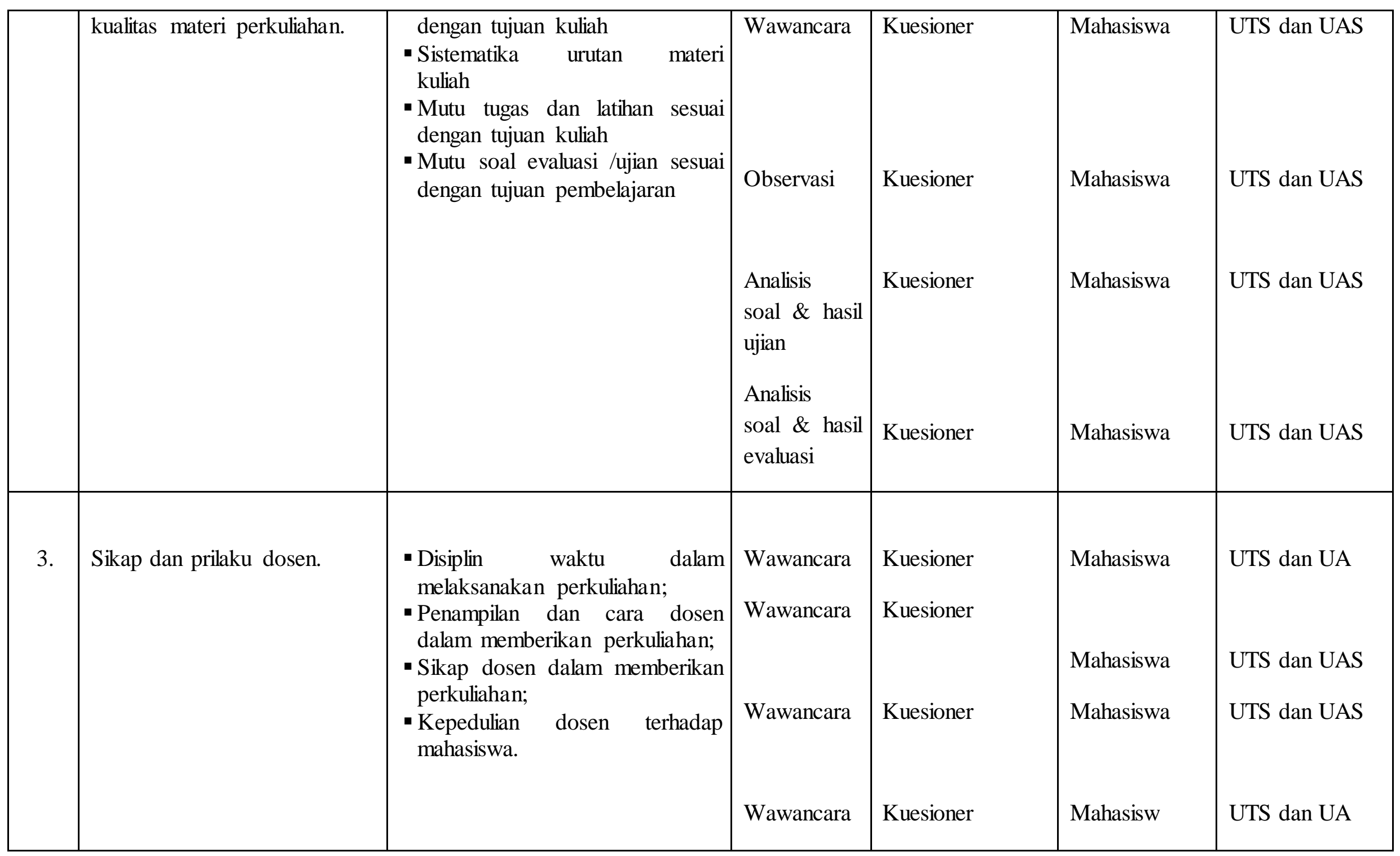




\begin{tabular}{|c|c|c|c|c|c|c|}
\hline 4. & $\begin{array}{l}\text { Penggunaan media dalam } \\
\text { pengajaran. }\end{array}$ & $\begin{array}{l}\text { - } \text { Ketepatan dalam } \\
\text { media; } \\
\text { - Penguasaan dosen } \\
\text { penggunaan media; } \\
\text { - Kreatif dalam } \\
\text { media; } \\
\text { - Kesesuaian media } \\
\text { tujuan matakuliah. }\end{array}$ & $\begin{array}{l}\text { Wawancara } \\
\text { Wawancara }\end{array}$ & Kuesioner & Mahasiswa & $\begin{array}{l}\text { UTS dan UAS } \\
\text { UTS dan UAS }\end{array}$ \\
\hline & & & Wawancara & Kuesioner & Mahasiswa & UTS dan UAS \\
\hline
\end{tabular}


TABEL 2

DAFTAR PERTANYAAN UNTUK MENGUMPULKAN DATA

\begin{tabular}{|c|c|c|c|c|}
\hline No. & $\begin{array}{l}\text { INFORMASI YA } \\
\text { DIBUTUHKA }\end{array}$ & & INDIKATOR & PERTANYAAN \\
\hline 1. & $\begin{array}{l}\text { Persepsi mahasiswa } \\
\text { kemampuan dosen } \\
\text { menyelenggarakan } \\
\text { pembelajaran. }\end{array}$ & $\begin{array}{r}\text { terhadap } \\
\text { dalam } \\
\text { kegiatan }\end{array}$ & $\begin{array}{l}\text { - Kemampuan dosen terhadap materi } \\
\text { kuliah; } \\
\text { - Kemampuan dosen dalam } \\
\text { menjelaskan materi kuliah; } \\
\text { - Kemampuan dosen dalam } \\
\text { memotivasi belajar mahasiswa; } \\
\text { - Kemampuan dosen bertanya dan } \\
\text { berdialog dengan mahasiswa; } \\
\text { - Kemampuan dosen dalam } \\
\text { meningkatkan minat belajar; } \\
\text { - Apakah dosen menyerahkan; } \\
\text { materi/hand out sebelum } \\
\text { perkuliahan; } \\
\text { - Kemampuan dosen membuat } \\
\text { perkuliahan menarik dan interaktif. }\end{array}$ & $\begin{array}{l}\text { 1. Dosen menguasai materi kuliah } \\
\mathrm{SS}-\mathrm{S}-\mathrm{RR}-\mathrm{KS} \text { - TS } \\
\text { 2. Dosen menyampaikan materi dengan jelas } \\
\mathrm{SS}-\mathrm{S}-\mathrm{RR}-\mathrm{KS} \text { - TS } \\
\text { 3. Dosen memberi dorongan belajar kepada } \\
\text { mahasiswa } \\
\mathrm{SS}-\mathrm{S}-\mathrm{RR}-\mathrm{KS} \text { - TS } \\
\text { 4. Dosen bertanya dan berdialog } \\
\mathrm{SS}-\mathrm{S}-\mathrm{RR}-\mathrm{KS}-\mathrm{TS} \\
\text { 5. Dosen mampu meningkat minat belajar } \\
\mathrm{SS}-\mathrm{S}-\mathrm{RR}-\mathrm{KS}-\mathrm{TS} \\
\text { 6. Dosem menyerahkanmateri kuliah } \\
\mathrm{SS}-\mathrm{S}-\mathrm{RR}-\mathrm{KS}-\mathrm{TS} \\
\text { 7. Dosen mampu membuat kuliah menarik } \\
\mathrm{SS}-\mathrm{S}-\mathrm{RR}-\mathrm{KS}-\mathrm{TS}\end{array}$ \\
\hline
\end{tabular}




\begin{tabular}{|c|c|c|c|}
\hline 2. & $\begin{array}{l}\text { Persepsi mahasiswa terhadap } \\
\text { kualitas materi perkuliahan }\end{array}$ & $\begin{array}{l}\text { - Kemutakhiran bahan ajar } \\
\text { - Materi yang disampaikan sesuai } \\
\text { dengan tujuan kuliah } \\
\text { - Sistematika urutan materi kuliah } \\
\text { - Mutu tugas dan latihan sesuai } \\
\text { dengan tujuan kuliah } \\
\text { - Mutu soal evaluasi /ujian sesuai } \\
\text { dengan tujuan pembelajaran }\end{array}$ & $\begin{array}{l}\text { 8. Bahan ajar yang disampaikan dosen } \\
\text { mutakhir } \\
\mathrm{SS}-\mathrm{S}-\mathrm{RR}-\mathrm{KS}-\mathrm{TS} \\
\text { 9. Dosen menyampaikan materi sesuai dengan } \\
\text { tujuan kuliah } \\
\mathrm{SS}-\mathrm{S}-\mathrm{RR}-\mathrm{KS}-\mathrm{TS} \\
\text { 10. Dosen menyampaikan materi sesuai dengan } \\
\text { urutan materi kuliah } \\
\mathrm{SS}-\mathrm{S}-\mathrm{RR}-\mathrm{KS}-\mathrm{TS} \\
\text { 11. Soal tugas dan latihan bermutu } \\
\mathrm{SS}-\mathrm{S}-\mathrm{RR}-\mathrm{KS}-\mathrm{TS} \\
\text { 12. Soal evaluasi dan ujian bermutu } \\
\mathrm{SS}-\mathrm{S}-\mathrm{RR}-\mathrm{KS}-\mathrm{TS}\end{array}$ \\
\hline 3. & Sikap dan prilaku dosen. & $\begin{array}{l}\text { - Disiplin waktu dalam } \\
\text { melaksanakan perkuliahan; } \\
\text { - Penampilan dan cara dosen dalam } \\
\text { memberikan perkuliahan; } \\
\text { - Sikap dosen dalam memberikan } \\
\text { perkuliahan; } \\
\text { - Kepedulian dosen terhadap } \\
\text { mahasiswa. }\end{array}$ & $\begin{array}{l}\text { 13. Apakah dosen hadir dan keluar tepat waktu } \\
\mathrm{SS}-\mathrm{S}-\mathrm{RR}-\mathrm{KS} \text { - TS } \\
\text { 14. Bagaimana penampilan dan cara berpakaian } \\
\text { dosen dalam menyampaikan kuliah } \\
\mathrm{SS}-\mathrm{S}-\mathrm{RR}-\mathrm{KS} \text { - TS } \\
\text { 15. Bagaiman sikap dosen saat memberikan } \\
\text { perkuliahan } \\
\mathrm{SS}-\mathrm{S}-\mathrm{RR}-\mathrm{KS} \text { - TS } \\
\text { 16. Apakah dosen perhatian dan peduli terhadap } \\
\text { mahasiswa } \\
\mathrm{SS}-\mathrm{S}-\mathrm{RR}-\mathrm{KS}-\mathrm{TS}\end{array}$ \\
\hline
\end{tabular}




\begin{tabular}{|c|c|c|c|c|}
\hline 4. & $\begin{array}{l}\text { Penggunaan } \\
\text { pengajaran. }\end{array}$ & media dalam & $\begin{array}{l}\text { - Ketepatan dalam memilih media ; } \\
\text { - Penguasaan dosen dalam } \\
\text { penggunaan media; } \\
\text { - Kreatif dalam pembuatan media; } \\
\text { - Kesesuaian media dengan tujuan } \\
\text { matakuliah. }\end{array}$ & $\begin{array}{l}\text { 17. Apakah media yang digunakan sesuai } \\
\mathrm{SS}-\mathrm{S}-\mathrm{RR}-\mathrm{KS}-\mathrm{TS} \\
\text { 18. Apakah dosen menguasai media yang dipilih } \\
\mathrm{SS}-\mathrm{S}-\mathrm{RR}-\mathrm{KS}-\mathrm{TS} \\
\text { 19. Apakah dosen kreatif dalam menyiapkan } \\
\text { media pembelajaran } \\
\mathrm{SS}-\mathrm{S}-\mathrm{RR}-\mathrm{KS} \text { - TS } \\
\text { 20. Apakah media yang digunakan sesuai dengan } \\
\text { tujuan mata kuliah } \\
\mathrm{SS}-\mathrm{S}-\mathrm{RR}-\mathrm{KS}-\mathrm{TS}\end{array}$ \\
\hline
\end{tabular}

\section{Keterangan :}

SS: Sangat Setuju

RR:Ragu-ragu

TS : Tidak Setuju

\section{S: Setuju}

KS : Kurang Setuju 


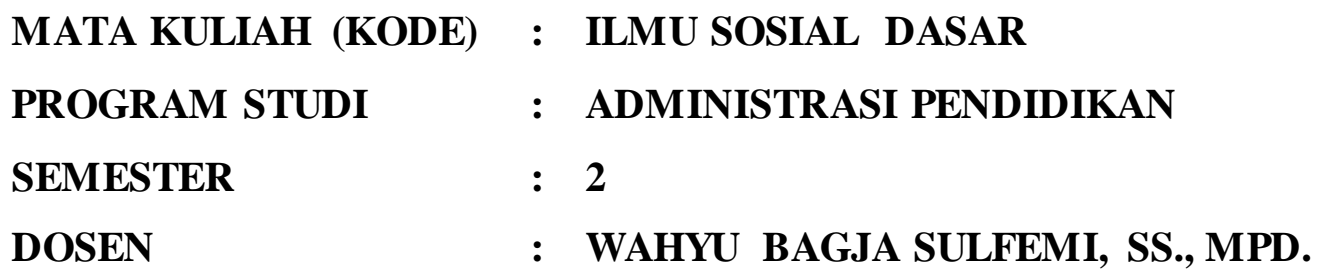

PROGRAM STUDI

SEMESTER

DOSEN

: ADMINISTRASI PENDIDIKAN

: 2

: WAHYU BAGJA SULFEMI, SS., MPD.

TAHAP EVALUASI

Hasil evaluasi matakuliah pada akhir semester genap 2012/2013 diperoleh informasi sebagai berikut :

1. Mahasiswa lebih banyak senang mendengarkan;

2. Mahasiswa kurang berani dalam mengeluarkan pendapat dan mengajukan pertanyaan;

3. Mahasiswa kurang mampu dalam menganalisis permasalahan yang diberikan;

4. Mahasiswa dalam pengumpulan tugas sering tidak tepat waktu;

5. Hasil penilaian belajar mahasiswa hanya sedang;

6. Motivasi mahasiswa rendah mungkin karena beragamnya tingkat pemahaman.

Untuk mengatasi masalah tersebut maka dilakukan rekontruksi mata kuliah, antara lain dengan cara :

1. Mengubah strategi pembelajaran, yang semula lebih banyak ceramah, diubah menjadi sedikit ceramah dengan variasi tanya jawab, diskusi dan latihan;

2. Memperbanyak studi kasus dalam proses pembelajaran sehingga mahasiswa dapat mengasah kemampuan analisis dalam pemecahan permasalahan Ilmu social budaya

3. Menambah bahan ajar yang baru.

4. Memberikan motivasi kepada mahasiswa diawal perkuliahan disertai contoh secara real dalam bentuk multimedia dan kisah-kisah orang sukses. 


\section{Langkah 1 : Menentukan Standar Kompetensi}

Evaluasi menunjukkan bahwa standar kompetensi mata kuliah Ilmu Sosial Dasar belum tercapai secara optimal. Pencapaian kompetensi yang harus diperbaiki adalah menganalisa permasalahan dan cara pemecahan masalah yang dituangkan ke dalam bahasa pemograman. Berdasarkan hasil evaluasi standar kompetensi ditentukan dan dirumuskan kembali agar mahasiswa mengerti, memahami dan dapat membuat menjelaskan konsep-konsep social dan budaya dasar

\section{Langkah 2 : Menentukan Kompetensi Dasar}

Selanjutnya standar kompetensi dijabarkan dalam tujuan yang spesifik yaitu 14 kompetensi dasar yang harus dicapai.

Tabel 1. Kompetensi Dasar Mata Kuliah Ilmu Sosial Dasar.

\begin{tabular}{|c|c|}
\hline No. & \multicolumn{1}{|c|}{ Kompetensi Dasar } \\
\hline 1. & $\begin{array}{l}\text { Setelah mengikuti pembelajaran ini mahasiswa dapat menjelaskan hakikat dan } \\
\text { ruang lingkup ISD, dan ISD sebagai alternatif solusi problem social budaya }\end{array}$ \\
\hline 2. & $\begin{array}{l}\text { Setelah mengikuti pembelajaran ini mahasiswa dapat menjelaskan hakikat } \\
\text { manusia sebagai mahluk budaya dan apresiasi kemanusiaan dan kebudayaan }\end{array}$ \\
\hline 3. & $\begin{array}{l}\text { Setelah mengikuti pembelajaran ini mahasiswa dapat merumuskan etika dan } \\
\text { estetika budaya, serta Konsep-konsep dasar manusia dan Problema kebudayaan }\end{array}$ \\
\hline
\end{tabular}




\begin{tabular}{|c|c|}
\hline 4. & $\begin{array}{l}\text { Setelah mengikuti pembelajaran ini mahasiswa menjelaskan hakikat manusia } \\
\text { sebagai individu dan mahluk sosial dan Fungsi dan peran manusia sebagai }\end{array}$ \\
\hline 5. & $\begin{array}{l}\text { Setelah mengikuti pembelajaran ini mahasiswa dapat menjelakan inamika } \\
\text { interaksi sosial dan Dilema kepentingan individu dan masyarakat }\end{array}$ \\
\hline 6. & $\begin{array}{l}\text { Setelah mengikuti pembelajaran ini mahasiswa dapat menjelaskan hakikat } \\
\text { peradaban Mahluk beradab dan masyarakat beradab }\end{array}$ \\
\hline 7. & $\begin{array}{l}\text { Setelah mengikuti pembelajaran ini mahasiswa dapat menjelaskan } \\
\text { evolusi budaya dan wujud peradaban Dinamika peradaban global serta }\end{array}$ \\
\hline 8. & $\begin{array}{l}\text { Setelah mengikuti pembelajaran ini mahasiswa dapat menjelaskan Hakikat } \\
\text { keragaman dan kesetaraanmanusia dan Kemajemukan dalam dinamika sosial }\end{array}$ \\
\hline 9. & $\begin{array}{l}\text { Setelah mengikuti pembelajaran ini mahasiswa dapat menjelaskan Keragaman } \\
\text { dan kesetaraan sebagai kekayaan sosial budaya Problematika keragaman dan } \\
\text { kesetaraan }\end{array}$ \\
\hline 10. & $\begin{array}{l}\text { Setelah mengikuti pembelajaran ini mahasiswa dapat menjelaskan Mengkaji } \\
\text { hakikat, fungsi, nilai, moral dan hukum dan Mengkaji keadilan, ketertiban dan }\end{array}$ \\
\hline 11. & $\begin{array}{l}\text { Setelah mengikuti pembelajaran ini mahasiswa dapat Merumuskan perwujudan } \\
\text { masyarakat bermoral dan taat hukum serta problematika nilai, moral, dan }\end{array}$ \\
\hline 12. & $\begin{array}{l}\text { Setelah mengikuti pembelajaran ini mahasiswa dapat menjelaska hakikat dan } \\
\text { makna sains, teknologi, dan seni bagi manusia serta Dampak penyalahgunaan }\end{array}$ \\
\hline 13. & $\begin{array}{l}\text { Setelah mengikuti pembelajaran ini mahasiswa dapat menjelaskan hakikat dan } \\
\text { makna lingkungan bagi manusia dan Kualitas penduduk dan lingkungan }\end{array}$ \\
\hline 14. & $\begin{array}{l}\text { Setelah mengikuti pembelajaran ini mahasiswa dapat mejelaskan problema } \\
\text { lingkungan sosial budaya dan Isu-isu penting tentang lintas budaya dan bangsa }\end{array}$ \\
\hline
\end{tabular}

\section{Langkah 3 : Menyusun Materi Perkuliahan}

Berdasarkan tujuan khusus yang telah dirumuskan maka disusun materi perkuliahan. Materi perkuliahan ini dapat menggunakan buku teks Ilmu social dasar. Materi perkuliahan selama ini disampaikan dalam bentuk diktat dan powerpoint sehingga mahasiswa mengalami kesulitan dapat memahami materi secara tuntas. Rekonstruksi materi yang dilakukan salah satunya yaitu dengan : 
1. Pembuatan modul dan diktat atau bahan ajar materi perkuliahan untuk memberi kesempatan mahasiswa untuk maju sesuai dengan kemampuannya masing-masing;

2. Memperbanyak studi kasus dalam proses pembelajaran sehingga mahasiswa dapat mengasah kemampuan analis is dalam pemecahan masalah;

3. Menambah beberapa materi pokok menjadi sub pokok

4. Dosen langsung mengimplementasikan dengan memberikan beberapa contoh ilmu social dan budaya dalam kehidupan sehari-hari

\section{Langkah 4 : Strategi Instruksional}

erdasarkan hasil evaluasi kemudian dilakukan rekonstruksi

strategis instruksional yaitu :

1. Mulai awal semester sudah disepakati kontrak perkuliahan antara dosen dan mahasiswa;

2. Menekankan dan melatih belajar aktif kepada mahasiswa didalam ruang kuliah dalam menyelesaikan studi kasus yang telah diberikan;

3. Memberikan tugas terstruktur kepada mahasiswa yang dapat dikerjakan diluar jam kuliah dan membahas tugas tersebut didalam pertemuan berikutnya;

4. Menggunakan strategi pembelajaran bervariasi yaitu ceramah interaktif, diskusi dan tanya jawab.

\section{Langkah 5 : Strategi untuk melakukan penilaian}

Soal tes dilakukan melalui kegiatan ujian (UTS/UAS) sesuai kompetensi yang diharapkan divcapai mahasiswa yaitu :

1. Menguji kompetensi dengan kemampuan menjelaskan konsep-konsep social dan budaya dasar

2. Menguji kompetensi dengan melaukan simulasi membuat konsep-konsep social dan budaya dasar

3. Menilai progress pencapaian kompetensi secara sistematis melalui pengerjaan tugas Memasukan penilaian untuk aspek kejujuran disiplin dan sikap afektif positif lainya yang ditujukan selama proses perkuliahan berlangsung 


\section{BAHAN AJAR}

\section{SESSI/PERKULIAHAN KE 1}

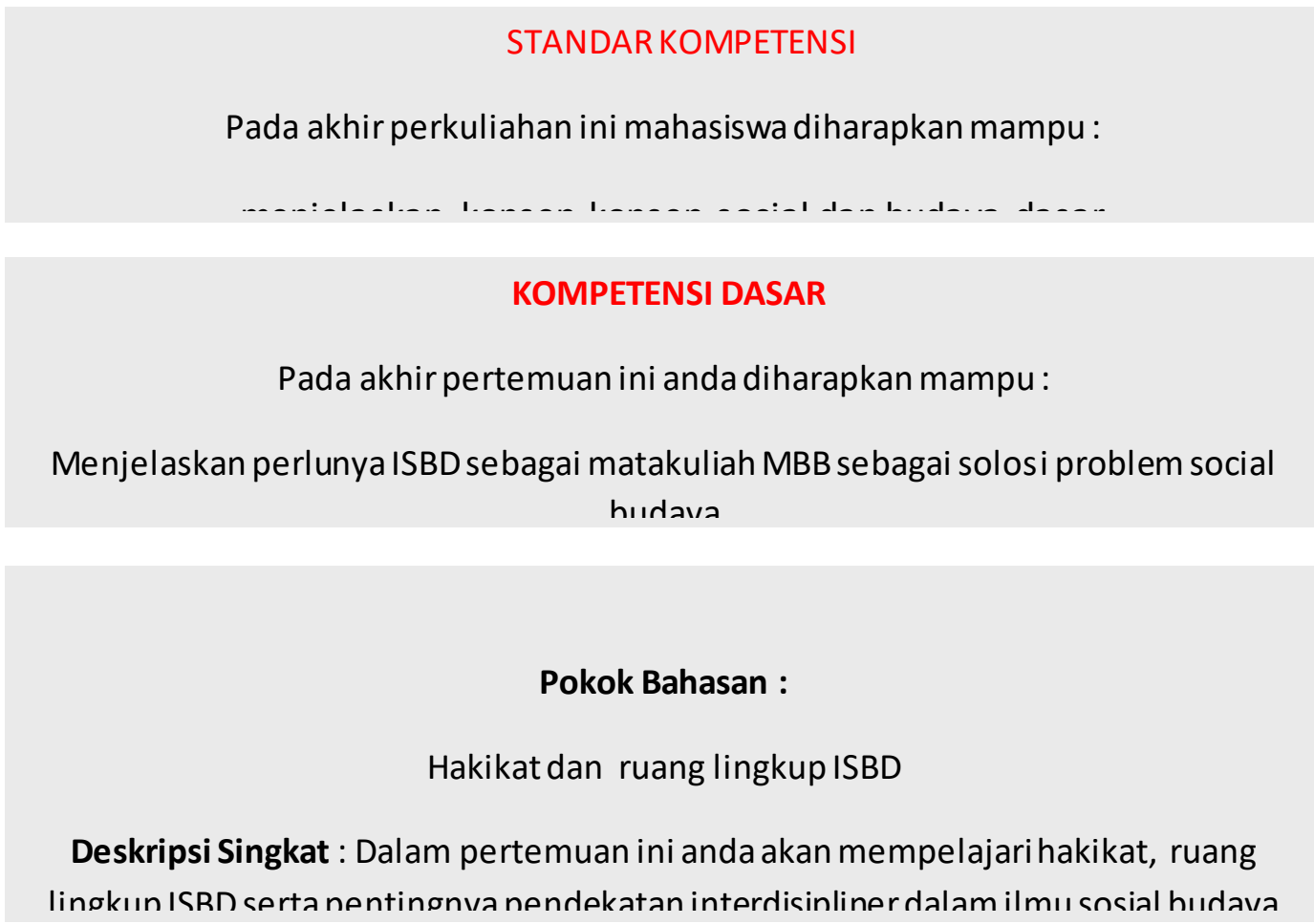

\section{Buku / bacaan wajib (bw)}

1. Sudiran, Florentinus. 2011. Ilmu Sosial Dasar. Laksbang : Jogyakarta

2. Setiadi, Elly M. dkk. 2006.. Ilmu Sosial Dasar Kencana. Jakarta

3. Schuon, F. 1997. Hakikat Manusia. Pustaka Pelajar. Yogakarta.

4. Soekanto, Soejono. 1983. Struktur Masyarakat. Rajawali. Jakarta.

5. Suleman, munandar. 1995. Ilmu Budaya Dasar. Eresco. Bandung

\section{Buku /bacaan anjuran (ba)}

1. Burhanuddin. 1988. Filsafat Manusia (Antropologi Metafisika). Bina Aksara. Jakarta

2. Baker, A. 1992. Ontologi: Metafisika Umum. Kanisius. Yogyakarta.

3. Geerzt, H. 1980. Aneka Budaya dan Komunitas di Indonsia. Yis dan FIS UI. Jakarta.

4. Kuntowijoyo. 1990. Metodologi Sejarah. Tiara Wacana. Yogakarta.

\section{Pertanyaan kunci/ tugas}


Ketika anda membaca bahan bacaan berikut, gunakan pertanyaan-pertanyaan berikut ini untuk memandu anda :

1. Jelaskan pengertian, tujuan \& fungsi ilmu sosial budaya dasar

2. Jelaskan pendekatan interdisipliner dalam ilmu sosial budaya

\section{Tugas}

Untuk memperdalam pemahaman anda mengenai materi di atas, silahkan mengerjakan Tugas, sebagai berikut :

1. Coba diskusikan dengan teman-teman anda yang Pengertian, tujuan \& fungsi ilmu sosial budaya dasar dan bagaimana ISD sebagai bahan alternatif solusi problem Sosial budaya

2. dimaksud Buatlah sumary dari perkuliahan ini dan presentasikan di pertemuan perkuliahan selanjutnya.

\section{MATERI PENYAJIAN}

Perkuliahan yang menyajikan materi hakikat dan ruang lingkup ISD dan ISD sebagai alternatif solusi Problem sosial budaya. Materi ini menjelaskan mengenai pengertian, tujuan dan fungsi ilmu sosial dasar. Sedang untuk pemecahan masalah mengenai problem sosial budaya juga diberikan agar anda dapat tangggap dan dapat menyelesaikan masalah sosial budaya dimasyarakat. .

\section{A. Hakikat dan Ruang lingkup ISD}

\section{Pengertian ISD}

Secara sederhana ISD adalah pengetahuan yang diharapkan dapat memberikan pengetahuan dasar dan pengertian umum tentang konsep-konsep yang diekembangkan untuk mengkaji masalah-masalah manusia dan kebudayaan. Istilah IBD dikembangkan petama kali di Indonesia sebagai pengganti istilah basic humanitiesm yang berasal dari istilah bahasa Inggris "the Humanities". Adapun istilah humanities itu sendiri berasal dari bahasa latin humnus yang astinya manusia, berbudaya dan halus. Dengan mempelajari the humanities diandaikan seseorang akan bisa menjadi lebih manusiawi, lebih berbudaya dan lebih halus. Dengan mempelajari the humanities diandaikan seseorang akan bisa menjadi lebih manusiawi, lebih berbudaya dan lebih halus. Dengan demikian bisa dikatakan bahwa the humanities berkaitan dengan nilai-nilai manusia sebagai homo humanus atau manusia berbudaya. Agar manusia menjadi humanus, 
mereka harus mempelajari ilmu yaitu the humanities disamping tidak meninggalkan tanggungjawabnya yang lain sebagai manusia itu sendiri.

Untuk mengetahui bahwa ilmu budaya dasar termasuk kelompok pengetahuan budaya lebih dahulu perlu diketahui pengelompokan ilmu pengetahuan. Prof Dr. Harsya Bactiar mengemukakan bahwa ilmu dan pengetahuan dikelompokkan dalam tiga kelompok besar yaitu:

Ilmu-ilmu sosial ( social scince ). ilmu-ilmu sosial bertujuan untuk mengkaji keteraturan-keteraturan yang terdapat dalam hubungan antara manusia. Untuk mengkaji hal ini digunakan metode ilmiah sebagai pinjaman dari ilmu-ilmu alamiah. Tapi hasil penelitiannya tidak 1005 benar, hanya mendekati kebenaran. Sebabnya ialah keteraturan dalam hubungan antara manusia initidak dapat berubah dari saat ke saat.

Pengetahuan budaya ( the humanities ) bertujuan untuk memahami dan mencari arti kenyataan-kenyataan yang bersifat manusiawi. Untuk mengkaji hal ini digunakan metode pengungkapan peristiwa-peristiwa dan kenyataan-kenyataan yang bersifat unik, kemudian diberi arti.

Pengetahuan budaya (the humanities) dibatasi sebagai pengetahuan yang mencakup keahlian (disilpin) seni dan filsafat. Keahlian inipun dapat dibagi-bagi lagi ke dalam berbagai hiding keahlian lain, seperti seni tari, seni rupa, seni musik,dll. Sedangkan ilmu budaya dasar (Basic Humanities) adalah usaha yang diharapkan dapat memberikan pengetahuan dasar dan pengertian umum tentang konsep-konsep yang dikembangkan untuk mengkaji masalah-masalah manusia dan kebudayaan. Dengan perkataan lain IBD menggunakan pengertian-pengertian yang berasal dari berbagai bidang pengetahuan budaya untuk mengembangkan wawasan pemikiran serta kepekaan mahasiswa dalam mengkaji masalah masalah manusia dan kebudayaan.

Ilmu budaya dasar berbeda dengan pengetahuan budaya. Ilmu budaya dasar dalam bahasa Ingngris disebut basic humanities. Pengetahuan budaya dalam bahas inggris disebut dengan istilah the humanities. Pengetahuan budaya mengkaji masalah nilai-nilai manusia sebagai mahluk berbudaya (homo humanus). Sedangkan ilmu budaya dasar bukan ilmu tentang budaya, melainkan mengenai pengetahuan dasar dan pengertian umum tentang konsep-konsep yang dikembangkan untuk mengkaji masalahmasalah manusia dan budaya.

\section{Tujuan Ilmu Sosial Budaya Dasar}


Tujuan ISD diharapkan dapat :

1. Mengusahakan kepekaan mahasiswa terhadap lingkungan budaya, sehingga mereka lebih mudah menyesuaikan diri dengan lingkungan yang baru, terutama untuk kepentingan profesi mereka

2. Memberi kesempatan kepada mahasiswa untuk memperluas pandangan mereka tentang masalah kemansiaan dan budaya serta mengembangkan daya kritis mereka terhadap persoalan-persoalan yang menyangkut kedua hal tersebut.

3. Mengusahakan agar mahasiswa, sebagai calon pemimpin bagnsa dan Negara serta ahli dalam bidang disiplin masing-masing tidak jatuh ke dalam sifat-sifat kedaerahan dan pengkotakan disiplin yang ketat

Menguasahakan wahana komunikasi para akademisi agar mereka lebih mampu berdialog satu sama lain. Dengan memiliki satu bekal yang sama, para akademisi diharapkan akan lebih lancer dalam berkomunikasi.

\section{Ruang Lingkup Ilmu Budaya Dasar}

Bertitik tolak dari kerangka tujuan yagn telah ditetapkan, dua masalah pokok bisa dipakai sebagai bahan pertimbangan untuk menentukan ruang lingkup kajian mata kuliah IBD. Kedua masalah pokok itu adalah :

1. Berbagai aspek kehidupan yang seluruhnya merupakan ungkapan masalah kemanusiaan dan budaya yang dapat didekati dengan menggunakan pengetahuan budaya (the humanities), baik dari segi masing-masing keahlian (disiplin) didalam pengetahuan budaya, maupun secara gabungan (antar bidang) berbagai disiplin dalam pengetahuan budaya

2. Hakekat manusia yang satu atau universal, akan tetapi yang beraneka ragam perwujudannya dalam kebudayaan masing-masing jaman dan tempat. Menilik kedua pokok masalah yang bisa dikaji dalam mata kuliah IBD, nampak dengan jelas bahwa manusia menempati posisi sentral dalam pengkajian. Manusia tidak hanya sebagai obyek pengkajian. Bagaimana hubungan manusia dengan alam, dengan sesame, dirinya sendiri, nilai-nilai manusia dan bagaimana pula hubungan dengan sang pencipta menjadi tema sentral dalam ISD.

\section{Fungsi ISD}

Memberikan pengetahuan dasar dan pengertian umum tentang konsep konsep yang dikembangkan untuk mengkaji gejala gejala social kebudayaan agar daya tanggap , 
persepsi, dan penalaran mahasiswa dalam menghadapi lingkungan social budaya dapat ditingkatkan sehingga kepekaan mahasiswa pada lingkungannya lebih besar.

\section{Visi dan Misi ISD}

Berkembangnya mahasiswa sebagai manusia terpelajar yang kritis, peka dan arif dalam memehami keragaman dan kesederajatan manusia yang dilandasi nilai nilai estetika, etika dan moral dalam kehidupan bermasyarakat. Memberikan landasan dan wawasan yang luas serta menumbuhkan sikap kritis, peka dan arif pada mahasiswa untuk memahami keragaman dan kesederajatan manusia dalam kehidupan bermasyarakat selaku individu dan makhluk social yang beradab serta bertanggung jawab terhadap sumber daya dan lingkungannya.

\section{B. ISD sebagai MBB}

Menjadi ilmuan dan professional yang berfikir kritis, kreatif, sistemik dan ilmiah, berwawasan luas, etis, estetis, serta memiliki apresiasi, kepekaan dan empati social , bersikap demokratis, berkeadaban serta ikut berperan mencari solusi pemecahan masalah social budaya secara arif.

Kompetensi MBB yang dituju ialah agar mahasiswa menguasai kemampuan berfikir rasional, berwawasan luas, berjiwa besar sebagai manusia intelektual beradab dan bermartabat yang bertanggung jawab terhadap :

Terwujudnya estetika, etika dan moral atau nilai nilai budaya bagi keteraturan, kebersamaa dan kesejahteraan hidup bermasyarakat serta terpeliharanya sumber daya alam dan lingkungannya

\section{Pentingnya pendekatan interdisipliner dalam ilmu sosial budaya}

Penggunaan pendekatan multisiplin dalam proses pembelajaran Ilmu Sosial Budaya Dasar bisa menggunakan pendekatan struktural, yaitu beberapa disiplin ilmu sosial atau disiplin ilmu budaya digunakan untuk mengkaji masalah, tetapi sistematika salah satu struktur disiplin tertentu masih terlihat dominan sebagai pisau analisisnya, karena masalah yang dikaji senagat erat dan banyak kaitannya dengan disiplin tertentu (misalnya masalah korupsi erta kaitannya dengan ilmu hukum, kemiskinan dengan ilmu ekonomi, banjir dengan ilmu geografi, dan sebagainya) sedangkan ilmu-ilmu yang lain sebagai penunjang analisisnya.

Selain itu, dengan menggunakan pendekatan fungsional, yaitu pembelajaran yang bertitik tolak dari masalah yang terdapat dalam masyarkat atau lingkungan mahasiswa 
atau masalah sosial-budaya dimana mahasiswa terlibat secara langsung. Oleh karena itu, pendekatan fungsional tidak berangkat dari satu disiplin ilmu, bahkan karena luasnya pembahasan, identitas disiplin ilmu hampir tidak kelihatan karena banyaknya konsep yang berhimpitan dan bersintesis. Misalnya saja ketika membahas pergaulan bebas di luar nikah, atau anarki pascareformasi dikaji faktor historis, faktor politis, faktor yuridis, faktor sosiologis, faktor kultural, serta faktor sosial-ekonomi.

Bisa juga diguanakan pendekatan interfield, yaitu bertitik tolak dari ruang lingkup yang luas, misalnya saja masalah humanitis dengan tema reformasi, pembangunan, pemilu, demokrasi, multikultur dsn 1 sin-lsin ysng dikaji dari berbagai ilmu yang cukup luas seperti bahasa, IPA, pendidikan, agama, teknologi dan sebagainya. Dalam pendekatan interfield ini dapat juga digunakan the area approach yang berusaha menyusun bahan kuliah berdasarkan kebudayaan suatu daerah, misalnya saja kebudayaan Bali, kebudayaan Jawa Barat, kebudayaan Betawi, dan lain-lain, atas dasar daerah tersebut maka aspek politik, sejarah, antropologi, ekonomi, pendidikan, teknologi, agama dan lain sebagainya ikut melengkapinya.

Model pembelajaran problem solving, inqury, klasifikasi nilai, science technologi and society, social action model, serta portopolio based learning sangat diperlukan untuk mengembangkan empat pilar pendidikan yang dikemukakan oleh UNESCO. Model pembelajaran yang disebut ini membutuhkan keterampilan mahasiswa untuk menguasai teknik pemecahan masalah.

John Dewey dalam bukunya, How The Think (1910). Mengemukakan langkahlangkah kegiatan ilmiah, yaitu mulai: (a) Merasakan adanya masalah; (b) Merumuskan masalah; (c) Membuat hipotesisi atau membuat pertanyaan-pertanyaan penelitian untuk memecahkan masalah; (d) Menetapkan sumber data yang akan dijadikan objek penelitian; (e) Membuat intsrumen untuk melakukan penelitian; (f) melakukan pengumpulan data; (g) Melakukan klasifikasi atau analisis data; (h) Menguji hipotesis atau Pembahasan hasil penelitian; (i) Rekomendasi.

Dalam konteks pendidikan, pengertian portofolio menurut D. Budimansyah (2002, h. 1-2) bisa diartikan sebagai "Wujud benda fisik" yaitu bundel, yaitu sekumpulan atau dokumentasi hasil pekerjaan peserta didik, seperti hasil bundelan pre-test, tugas, post-test, dan lain-lain. Bisa juga diarrtikan sebagai "kegiatan social paedagogis", yaitu collection of learning experience yang terdapat dalam pikiran peserta didik baik yang 
berwujud pengetahuan, sikap, maupun keterampilan. Sedangkan sebagai model pembelajaran Boediono (2001) mengataka bahwa portofolio merupakan bentuk dari praktik belajar kewarganegaraan, yaitu inovasi pembelajaran yang dirancang untuk membantu peserta didik memahami teori secara mendalam melalui pengalaman belajar praktik-empirik.

\section{ISD Sebagai Alternatif Pemecahan Masalaha Sosial Budaya}

Penyajian mata kuliah ilmu budaya dasar tidak lain merupakan usaha yang diharapkan dapat memberikan pengetahuan dasar dan pengertian umum tentang konsepkonsep yang dikembangkan untuk mengkaji masalah-masalah manusia dan kebudayaan. Dengan demikian mata kuliah ini tidak dimaksudkan untuk mendidik ahli-ahli dalam salah satu bidang keahlian yang termasuk didalam pengetahuan budaya (the humanities) akan tetapi IBD semata-mata sebagai salah satu usaha untuk mengembangkan kepribadian mahasiswa dengan cara memperluas wawasan pemikiran serta kemampuan kritikalnya terhadap nilai-nlai budaya, baik yang menyangkut orang lain dan alam sekitarnya, maupun yang menyangkut dirinya sendiri.

Untuk bisa menjangkau tujuan tersebut ISD diharapkan dapat :

Mengusahakan kepekaan mahasiswa terhadap lingkungan budaya, sehingga mereka lebih mudah menyesuaikan diri dengan lingkungan yang baru, terutama untuk kepentingan profesi mereka (2) Memberi kesempatan kepada mahasiswa untuk memperluas pandangan mereka tentang masalah kemansiaan dan budaya serta mengembangkan daya kritis mereka terhadap persoalan-persoalan yang menyangkut kedua hal tersebut. (3) Mengusahakan agar mahasiswa, sebagai calon pemimpin bagnsa dan Negara serta ahli dalam bidang disiplin masing-masing tidak jatuh ke dalam sifat-sifat kedaerahan dan pengkotakan disiplin yang ketat

Menguasahakan wahana komunikasi para akademisi agar mereka lebih mampu berdialog satu sama lain. Dengan memiliki satu bekal yang sama, para akademisi diharapkan akan lebih lancer dalam berkomunikasi dan merupakan ISD Sebagai Alternatif Pemecahan Masalaha Sosial Budaya

\section{Senarai (summary)}

Secara sederhana ISD adalah pengetahuan yang diharapkan dapat memberikan pengetahuan dasar dan pengertian umum tentang konsep-konsep yang diekembangkan untuk mengkaji masalah-masalah manusia dan kebudayaan. Tujuan ISD bertujuan 
mengusahakan kepekaan mahasiswa agar lebih mudah menyesuaikan diri dengan lingkungan untuk memperluas pandangan mereka tentang masalah kemansiaan dan budaya serta mengembangkan daya kritis mereka terhadap persoalan-persoalan. 


\section{BAHAN AJAR}

\section{SESSI/PERKULIAHAN KE 2}

\section{STANDAR KOMPETENSI}

Pada akhir perkuliahan ini mahasiswa diharapkan mampu :

KOMPETENSI DASAR

Pada akhir pertemuan ini anda diharapkan mampu :

Merumuskan manusia sebagai mahluk berbudaya, beretika, dan berestetika.

\section{Pokok Bahasan :}

Manusia sebagai mahluk berbudaya, beretika, dan berestetika

Deskripsi Singkat : Dalam pertemuan ini anda akan mempelajari hakikat manusia sebagai mahluk budaya, apresiasi terhadap kemanusiaan, serta etika dan estetika berbudaya serta Memanusiakan manusia.

\section{Buku / bacaan wajib (bw)}

1. Sudiran, Florentinus. 2011. Ilmu Sosial Dasar. Laksbang : Jogyakarta

2. Setiadi, Elly M. dkk. 2006.. Ilmu Sosial Dasar Kencana. Jakarta

3. Schuon, F. 1997. Hakikat Manusia. Pustaka Pelajar. Yogakarta.

4. Soekanto, Soejono. 1983. Struktur Masyarakat. Rajawali. Jakarta.

5. Suleman, munandar. 1995. Ilmu Budaya Dasar. Eresco. Bandung

6.

\section{Buku/bacaan anjuran (ba)}

1. Burhanuddin. 1988. Filsafat Manusia (Antropologi Metafisika). Bina Aksara. Jakarta

2. Baker, A. 1992. Ontologi: Metafisika Umum. Kanisius. Yogyakarta. 
3. Geerzt, H. 1980. Aneka Budaya dan Komunitas di Indonsia. Yis dan FIS UI. Jakarta.

4. Kuntowijoyo. 1990. Metodologi Sejarah. Tiara Wacana. Yogakarta.

\section{Pertanyaan kunci/ tugas}

Ketika anda membaca bahan bacaan berikut, gunakan pertanyaan-pertanyaan berikut ini untuk memandu anda :

1. Apa yang dimaksud dengan hakikat manusia sebagai mahluk budaya

2. Bagaimana apreasi manusia terhadap kebudayaan

\section{Tugas}

Untuk memperdalam pemahaman anda mengenai materi di atas, silahkan mengerjakan Tugas, sebagai berikut :

1. Coba diskusikan dengan teman-teman anda yang dimaksud dengan hakikat manusia sebagai mahluk budaya dan Bagaimana apreasi manusia terhadap kebudayaan

2. Buatlah sumary dari perkuliahan ini dan presentasikan di pertemuan perkuliahan selanjutnya.

\section{MATERI PENYAJIAN}

Perkuliahan yang menyajikan materi mengenai manusia sebagai makhluk budaya, dimana didalam dipaparkan mengenai Hakikat Manusia Sebagai Makhluk Budaya. Di mataeri ini dijelaskan mengenain pegertian dan kenapa budaya timbul. Kemudian materi berikutnya apresiasi terhadap kemanusiaan dan kebudayaan, disini jelaskan mengenai apresiasi manusia terhadapa kemanusian dan kebudayaan

\section{. A. Hakikat Manusia Sebagai Makhluk Budaya}

Manusia adalah salah satu makhluk Tuhan di dunia. Makhluk Tuhan dialam fana ini ada empat macam, yaitu alam, tumbuhan, binatang, dan manusia. Sifat-sifat yang dimiliki keempat makhluk Tuhan tersebut sebagai berikut.

1. Alam memiliki sifat wujud 
2. Tumbuhan memiliki sifat hidup dan wujud

3. Binatang memiliki sifat wujud, hidup dan dibekali nafsu

4. Manusia memiliki sifat wujud, hidup dibekali nafsu serta akal budi

Akal budi merupakan pemberian sekaligus potensi dalam diri manusia yang tidak dimiliki makhluk lain. Kelebihan manusia dibandingkan makhluk lain terletak pada akal budi. Anugerah Tuhan akan akal budilah yang membedakan manusia dari makhluk lain. Akal adalah kemampuan berpikir manusia sebagai kodrat alami yang dimiliki. Berpikir merupakan perbuatan operasional dari akal yang mendorong untuk aktif berbuat demi kepentingan dan peningkatan hidup manusia. Jadi, fungsi dari akal adalah berpikir. Karena manusia yang dianugerahi akal maka manusia dapat berpikir. kemampuan berpikir manusia juga digunakan untuk memecahkan maslaah-masalah hidup yang dihadapi.

Budi berarti juga akal. Budi berasal dari bahasa Sansekerta budha yang artinya akal. Budi menurut kamus lengkap Bahasa Indonesia adalah bagian dari kata hati yang berupa panduan akal dan perasaan dan yang dapat membedakan baik-buruk sesuatu. Budi dapat pula berarti tabiat, perangai dan akhlak. Sutan Takdir Alisyahbana mengungkapkan bahwa budilah yang menyebabkan manusia mengembangkan suatu hubungan yang bermakna dengan alam sekitarnya dengan jalan memberikan penilaian objektif terhadap objek dan kejadian.

Dengan akal budinya, manusia mampu menciptakan, mengkreasi, memperlakukan, memperbarui, memperbaiki, mengembangkan dan meningkatkan sesuatu yang ada untuk kepentingan hidup manusia. Contohnya manusia bisa membangun rumah, membuat aneka masakan, menciptakan beragam jenis pakaian, membuat alat transportasi, sarana komunikasi dan lain-lain. Binatang pun bisa membuat rumah dan mencari makan. Akan tetapi, rumah dan makanan suatu jenis makanan tidak pernah berubah dan berkembang. Rumah burung (sarang) dari dulu sampai sekarang tetap saja wujudnya, tidak ada pembaharuan dan peningkatan. Manusia dengan kemampuan akal budinya bisa memperbaharui dan mengembangkan sesuatu untuk kepentingan hidup. 
Kepentingan hidup manusia adalah dalam rangka untuk memenuhi kebutuhan hidup. Secara umum, kebutuhan manusia dalam kehidupan dapat dibedakan menjadi dua. Pertama, kebutuhan yang bersifat kebendaan (sarana-prasarana) atau badani atau ragawi atau jasmani/biologis. Contohnya adalah makan, minum, bernafas, istirahat dan seterusnya. Kedua, kebutuhan yang bersifat rohani atau mental atau psikologi. Contohnya adalah kasih sayang, pujian perasaan aman, kebebasan, dan sebagainya.

Abram Maslow seorang ahli psikologi, berpendapat bahwa kebutuhan manusia dalam hidup dibagi menjadi lima tingkatan. Kelima tingkatan tersebut adalah sebagai berikut :

1. Kebutuhan psikologis (physiological needs). Kebutuhan ini merupakan kebutuhan dasar, primer dan vita. Kebutuhan ini menyangkut fungsi-fungsi biologis dasar dari organisme manusia, seperti kebutuhan akan makanan, pakaian tempat tinggal, sembuh dari sakit, kebutuhan seks dan sebagainya.

2. Kebutuhan akan rasa aman dan perlindungan (safety and security needs). Kebutuhan ini menyangkut perasaan, seperti bebas dari rasa takut, terlindung dari bahaya dan ancaman penyakit, perang, kemiskinan, kelaparan, perlakuan tidak adil dan sebagaimya.

3. Kebutuhan sosial (sosial needs). Kebutuhan ini meliputi kebutuhan akan dicintai, diperhitungkan sebagai pribadi, diakui sebagai anggota kelompok, rasa setia kawan, kerja sama, persahabatan, interaki, dan seterusnya.

4. Kebutuhan akan penghargaan (esteem needs). Kebutuhan ini meliputi kebutuhan dihargainya kemampuan, kedudukan jabatan, status, pangkat, dan sebagainya.

5. Kebutuhan akan aktualisasi diri (self actualization). Kebutuhan ini meliputi kebutuhan untuk memaksimalkan penggunaan potensi-potensi, kemampuan, bakat, kreativitas, ekspresi diri, prestasi dan sebagainya.

Menurut Maslow, kebutuhan manusia pertama-tama diawali dari kebutuhan psiklogis atau paling mendesak kemudian secara bertahap beralih ke kebutuhan tingkat di atasnya sampai tingkatan tertinggi, yaitu kebutuhan aktualisasi diri. Beliau menjelaskan bahwa kita tidak dapat memenuhi kebutuhan kita yang lebih tinggi kalau kebutuhan yang lebih rendah belum terpenuhi. Itu berarti kebuthan nomor lima akan 
diupayakan pemenuhannya kalau kita sudah memenuhi kebutuhan-kebutuhan sebelumnya. Jadi, kebutuhan manusia bertingkat dan membentuk hirarki.

Dengan akal budi, manusia tidak hanya untuk memenuhi kebutuhan hidup, tetapi juga mampu mempertahankan serta meningkatkan derajatnya sebagi makhluk yang tinggi bila dibandingkan dengan makhluk lainnya. Manusia tidak sekedar homo, tetapi human (manusia yang manusiawi). Dengan demikian, manusia memiliki dan mampu mengembangkan sisi kemanusiaannya.

Dengan akal budi manusia mampu menciptakan kebudayaan. Kebudayaan pada dasarnya adalah hasil akal budi manusia dalam interaksinya, baik dengan alam maupun manusia lainnya. Manusia merupakan makhluk yang berbudaya. Manusia adalah pencipta kebudayaan.

\section{B. Apresiasi Terhadap Kemanusiaan dan Kebudayaan}

Istilah kemanusiaan berasal dari kata manusia mendapat tambahan awalan ke-dan akhiran-an sehingga menjadikan kata benda abstrak. Manusia menunjuk pada benda konkret, sedangkan kemanusiaan merupakan kata beda abstrak. Dengan demikian kemanusiaan disebut dengan human.

Kemanusiaan berarti hakikat dan sifat-sifat khas manusia sebagai makhluk yang tinggi harkat matabatnya. Kemanusiaan menggambarkan ungkapan akan hakikat dan sifat yang seharusya dimiliki oleh makhluk yang bernama manusia. Kemanusiaan merupakan prinsip atau nilai yang berisi keharusan/tutunan untuk berkesuaian dengan hakikat dari manusia.

Hakikat manusia bisa dipandang secara segmental atau dalam arti parsial. Misalkan manusia dikatakan sebagai homo economicus, homo faber, homo socius, homo homini lupus, zoon politicon, dan sebagainya. Namun pandangan demikian tidak bisa menjelaskan hakikat manusia secara utuh.

Hakikat manusia Indonesia berdasarkan Pancasila sering dikenal sebagai sebutan hakikat kodrat monopluralis.

Hakikat manusia terdiri atas : 
1. Monodualis susunan kodrat manusia yang terdiri dari aspek keragaan, meliputi wujud materi argonasis benda mati, vegetatif, dan animalis, serta aspek kejiwaan meliputi cipta, rasa dan karsa.

2. Monodualis sifat kodrat manusa terdiri atas segi individu dan segi sosial.

3. Monodualis kedudukan kodrat meliputi segi keberadaan manusia sebagai makhluk yang berkepribadian merdeka (berdiri sendiri) sekaligus juga menunjukkan keterbatasannya sebagai makhluk Tuhan.

Karena manusia memiliki harkat dan derajat yang tinggi maka manusia hendaknya mempertahankan hal tersebut. Dalam upaya mempertahankan dan meningkatkan harkat dan martabatnya tersebut, maka prinsip kemanusiaan berbicara. Prinsip kemanusiaan mengandung arti adanya penghargaan dan penghormatan terhadap harkat dan martabat manusia yang luhur itu. Semua manusia adalah luhur, karena itu manusia tidak harus dibedakan perlakuannya karena perbedaan suku, ras, keyakinan status sosial ekonomi, asal-usul dan sebagainya.

Ada ungkapan bahwa the mankind is one ( Kemanusiaan adalah satu ). Dengan demikian, sudah sewajarnya antar sesama manusia tidak saling menindas, tetapi saling menghargai dan saling menghormati dengan pijakan prinsip kemanusiaan. Prinsip kemanusiaan yang ada dalam diri manusia menjadi penggerak manusia untuk berperilaku yang seharusnya sebagai manusia.

Dalam pancasila sila kedua terdapat konsep kemanusiaan yang adil dan beradab. Kemanusiaan yang adil dan beradab berarti sikap dan perbuatan manusia yang sesuai dengan kodrat hakikat manusia yang sopan dan susila yang berdasarkan atas nilai dan norma moral. Kemanusiaan yang adil dan beradab adalah kesadaran akan sikap dan perbuatan yang didasarkan pada budi nurani manusia yang dihubungkan dengan normanorma baik terhadap diri-sendiri, sesama manusia, maupun terhadap lingkungannya.

Kebudayaan berasal dari Bahasa Sansekerta, yaitu buddhayah yang merupakan bentuk jamak dari buddhi (budi atau akal) diartikan sebagai hal-hal yang berkaitan dengan budi dan akal. Ada pendapat lain mengatakan budaya berasal dari kata budi dan daya. Budi merupakan unsur rohani, sedangkan daya adalah unsur jasmani manusia. Dengan demikian, budaya merupakan hasil budi dan daya dari manusia. 
Dalam bahasa Inggris, kebudayaan disebut culture, yang berasal dari kata latin colere, yaitu mengolah dan mengerjakan. Dalam Bahsa Belanda, cultuur berarti sama dengan culture. Culture atau cultuur bisa diartikan juga sebagi mengolah tanah dan bertani. Dengan demikian, kata budaya ada hubungannya dengan kemampuan manusia dalam mengelola sumber-sumber kehidupan, dalam hal ini pertanian. Kata culture juga kadang diterjemahkan sebagai kultur dalam bahasa Indonesia.

Definisi kebudayaan telah banyak dikemukakan oleh para ahli. Beberapa contoh sebagai berikut :

1. Herskovits memandang kebudayaan sebagai sesuatu yang turun temurun dari suatu generasi ke generasi yang lain, yang kemudian disebut sebagai super organik.

2. Andreas Eppink menyatakan bahwa kebudayaan mengandung keseruhan pengertian, nilai, norma, ilmu pengetahuan, serta keseluruhan struktur-struktur sosial, religius, dan lain-lain, ditambah lagi dengan segala intelektual dan artistik yang menjadi ciri khas suatu masyarakat.

3. Eward B, Taylor mengemukakan bahwa kebudayaan merupakan keseluruhan yang kompleks, yang didalamnya mengandung pengetahuan, kepercayaan, kesenian, moral, hukum, adat istiadat, dan kemampuan-kemampuan lain yang didapat seseorang sebagai anggota suatu masyarakat.

4. Selo Soemardjan dan Soelaiman Soemardi mengatakan kebudayaan adalah sarana hasil karya, rasa dan cipta masyarakat.

5. Koentjaraningrat berpendapat bahwa kebudayaan adalah keseluruhan gagasan dan karya manusia yang harus dibiasakan dengan belajar besirat dari hasil budi pekerti

Dari berbagai definisi tersebut, dapat diperoleh pengertian mengenai kebudayaan sebagai sistem pengetahuan yang meliputi sistem ide atau gagasan yang terdapat dalam pikiran manusia, sehingga dalam kehidupan sehari-hari, kebudayaan itu bersifat abstrak. Sedangkan perwujudan kebudayaan adalah benda- benda yang diciptakan oleh manusia sebagai makhluk yang berbudaya, berupa perilaku dan berupa benda- benda yang bersifat nyata, misalnya pola-pola perilaku, bahasa, peralatan hidup, organisasi sosial, religi, seni, dan lain-lain, yang kesemuanyan ditujukan untuk membantu Manusia dalam melangsungkan kehidupan bermasyarakatnya. 
J.J Hoeningman membagi wujud kebudayaan menjadi tiga, yaitu gagasan, aktivitas, dan artefak.

\section{a. Gagasan (wujud ideal)}

Wujud ideal kebudayaan adalah kebudayaan yang berbentuk kumpulan ide, gagasan, nilai, norma, peraturan, dan sebagainya yang sifatnya abstrak; tidak dapat diraba atau disentuh. Wujud kebudayaan ini terletak dalam kepala atau di alam pemikiran warga masyarakat. Jika masyarakat tersebut menyatakan gagasan mereka itu dalam bentuk tulisan, maka lokasi dari kebudayaan ideal itu berada dalam karangan dan buku-buku hasil karya para penulis warga masyarakat tersebut.

\section{b. Aktivitas (tindakan)}

Aktivitas adalah wujud kebudayaan sebagai suatu tindakan berpola dari manusia dalam bermasyarakat itu. Wujud ini sering pula disebut dengan sistem sosial. Sistem sosial ini terdiri dari aktivitas-aktivitas manusia yang saling berinteraksi, mengadakan kontak, serta bergaul dengan manusia lainnya menurut pola-pola tertentu yang berdasarkan adat tata kelakuan. sifatnya konkret, terjadi dalam kehidupan sehari-hari, dan dapat diamati dan didokumentasikan.

\section{c. Artefak (karya)}

Artefak adalah wujud kebudayaan fisik yang berupa hasil dari aktivitas, perbuatan, dan karya semua manusia dalam masyarakat berupa benda benda atau halhal yang dapat diraba, dilihat dan didokumentasikan. Sifatnya paling kongkret diantara ketiga wujud kebudayaan,

1. Koentjaraningrat membagi wujud kebudayaan menjadi tiga pula, yaitu

2. Suatu kompleks ide, gagasan, nilai norma dan sebagainya

3. Suatu kompleks aktivitas atau tindakan berpola dari manusia dalam bermasyarakat

4. Suatu benda-benda hasil karya manusia

Sedangkan mengenai unsur kebudayaan, dikenal adanya tiga usur kebudayaan yang bersifat universal. Ketujuh unsur tersebut dikatakan universal karena dapat dijumpai dalam setiap kebudayaan dimanapun dan kapan pun berada. 
Tujuh unsur kebudayaan tersebut yaitu :

1. Sistem peralatan dan perlengkapan hidup

2. Sistem mata pencaharian hidup

3. Sistem kemasyarakatan atau organisasi sosial

4. Bahasa

5. Kesenian

6. Sistem pengetahuan

7. Sistem religi

Manusia merupakan pencipta kebudayaan karena manusia dianugerahi akal dan budi daya. Dengan akal dan budi daya itulah manusia menciptakan dan mengembangkan kebudayaan. Terciptanya kebudayaan adalah hasil interaksi manusia dengan segala isi alam raya ini. Hasil interaksi binatang dengan alam sekitar tidak membentuk kebudayaan, tetapi hanya menghasilkan pembiasaan saja. Hal ini karena binatang tidak dibekali akal budi, tetapi hanya nafsu dan naluri tingkat rendah.

Karena manusia adalah pencipta kebudayaan maka manusia adalah makhluk berbudaya. Kebudayaan adalah ekspresi eksistesi manusia di dunia. Dengan kebudayaannya manusia mampu menampakkan jejak-jejaknya dalam panggung sejarah dunia.

\section{Senarai (summary)}

Kebudayaan berasal dari Bahasa Sansekerta, yaitu buddhayah yang merupakan bentuk jamak dari buddhi (budi atau akal) diartikan sebagai hal-hal yang berkaitan dengan budi dan akal. Sehingga budaya merupakan hasil budi dan daya dari manusia. Dengan akal budinya, manusia mampu menciptakan, mengkreasi, memperlakukan, memperbarui, memperbaiki, mengembangkan dan meningkatkan sesuatu yang ada untuk kepentingan hidup manusia. Manusia dengan kemampuan akal budinya bisa memperbaharui dan mengembangkan sesuatu untuk kepentingan hidup. Kebudayaan adalah ekspresi eksistesi manusia di dunia. Dengan kebudayaannya manusia mampu menampakkan jejak-jejaknya dalam panggung sejarah dunia. 


\section{BAHAN AJAR}

\section{SESSI/PERKULIAHAN KE 3}

\section{STANDAR KOMPETENSI}

Pada akhir pertemuan ini mahasiswa diharapkan mampu :

menjelaskan konsep-konsep social dan budaya dasar

\section{KOMPETENSI DASAR}

Pada akhir pertemuan ini anda diharapkan mampu :.

Merumuskan manusia sebagai mahluk berbudaya, beretika, dan berestetika

\section{Pokok Bahasan :}

Manusia sebagai mahluk berbudaya, beretika, dan berestetika

Deskripsi Singkat : Dalam pertemuan ini anda akan mempelajari hakikat manusia sebagai mahluk budaya, apresiasi terhadap kemanusiaan, serta etika dan estetika berbudaya serta memanusiakan manusia.

\section{Buku / bacaan wajib (bw)}

1. Sudiran, Florentinus. 2011. Ilmu Sosial Dasar. Laksbang : Jogyakarta

2. Setiadi, Elly M. dkk. 2006.. Ilmu Sosial Dasar Kencana. Jakarta

3. Schuon, F. 1997. Hakikat Manusia. Pustaka Pelajar. Yogakarta.

4. Soekanto, Soejono. 1983. Struktur Masyarakat. Rajawali. Jakarta.

5. Suleman, munandar. 1995. Ilmu Budaya Dasar. Eresco. Bandung 


\section{Buku /bacaan anjuran (ba)}

1. Burhanuddin. 1988. Filsafat Manusia (Antropologi Metafisika). Bina Aksara. Jakarta

2. Baker, A. 1992. Ontologi: Metafisika Umum. Kanisius. Yogyakarta.

3. Geerzt, H. 1980. Aneka Budaya dan Komunitas di Indonsia. Yis dan FIS UI. Jakarta.

4. Kuntowijoyo. 1990. Metodologi Sejarah. Tiara Wacana. Yogakarta.

\section{Pertanyaan kunci/ tugas}

Ketika anda membaca bahan bacaan berikut, gunakan pertanyaan-pertanyaan berikut ini untuk memandu anda :

1. Apa yang dimaksud budaya

2. Apa yang dimaksud Etika dan Estetika dalam Kebudayaan

3. Bagaimana apreasi manusia terhadap kebudayaan

\section{Tugas}

Untuk memperdalam pemahaman anda mengenai materi di atas, silahkan mengerjakan Tugas, sebagai berikut :

1. Coba diskusikan dengan teman-teman anda yang dimaksud dengan hakikat manusia sebagai mahluk budaya

2. Buatlah sumary dari perkuliahan ini dan presentasikan di pertemuan perkuliahan selanjutnya.

\section{MATERI PENYAJIAN}

Perkuliahan yang menyajikan materi mengenai manusia sebagai makhluk budaya, dimana didalam dipaparkan mengenai Hakikat Manusia Sebagai Makhluk Budaya Etika dan Estetika Kebudayaan memanusiakan manusia. Didalamnya dijabarkan mengenai etika manusia dalam berbudaya dan Estetika Manusia dalam Berbudaya. Selanjutnya materi ini membahas mengenai Memanusiakan manusia. 


\section{A. Etika dan Estetika Kebudayaan}

\section{Etika Manusia dalam Berbudaya}

Kata etika berasal dari bahasa Yunani, yaitu ethos. Secara etimologis, etika adalah ajaran tentang baik-buruk, yang diterima umum atau tentang sikap, perbuatan, kewajiban, dan sebagainya. Etika bisa disamakan artinya dengan moral (mores dalam bahasa latin), akhlak, atau kesusilaan. Etika berkaitan dengan masalah nilai, karena etika pada pokoknya membicarakan masalah-masaah yang berkaitan dengan predikat nilai susila, atau tidak susila, baik dan buruk. Dalam hal ini, etika termasuk dalam kawasan nilai, sedangkan nilai etika itu sendiri berkaitan dengan baik-buruk perbuatan manusia.

Namun, etika memiliki makna yang bervariasi. Bertens menyebutkan ada tiga jenis makna etika sebagai berikut :

1. Etika dalam arti nilai-nilai atau norma yang menjadi pegangan bagi seseorang atau kelompok orang dalam mengatur tingkah laku.

2. Etika dalam arti kumpulan asas atau nilai moral (yang dimaksud disini adalah kode etik)

3. Etika dalam arti ilmu atau ajaran tentang yang baik dan yang buruk. Disini etika sama artinya dengan filsafat moral.

Etika sebagai nilai dan norma etik atau moral berhubungan dengan makna etika yang pertama. Nilai-nilai etik adalah nilai tentang baik buruk kelakuan manusia. Nilai etik diwujudkan kedalam norma etik, norma moral, norma kesusilaan.

Norma etik berhubungan dengan manusia sebagai individu karena menyangkut kehidupan pribadi. Pendukung norma etik adalah nurani individu dan bukan manusia sebagai makhluk sosial atau sebagai anggota masyarakat yang terorganisir. Norma ini dapat melengkapi ketidakseimbangan hidup pribadi dan mencegah kegelisahan diri sendiri.

Norma etik ditujukan kepada umat manusia agar tebetuk kebaikan akhlak pribadi guna penyempurnaan manusia dan melarang manusia melakukan perbuatan jahat. Membunuh, berzina, mencuri, dan sebagaiya. Tidak hanya dilarang oleh norma kepercayaan atau keagamaan saja, tetapi dirasaan juga sebagai bertentangan dengan 
(norma) kesusilaan dalam setia hati nurani manusia. Norma etik hanya membebani manusia dengan kewajiban-kewajiban saja.

Asal atau sumber norma etik adalah dari manusia sendiri yang bersifat otonom dan tidak ditujukan kepada sikap lahir, tetapi ditujukan kepada sikap batin manusia. Batinnya sendirilah yang mengancam perbuatan yang melanggar norma kesusilaan dengan sanksi. Tidak ada kekuasaaan diluar dirinya yang memaksakan sanksi itu. Kalau terjadi pelanggaran norma etik, misalnya pencurian atau penipuan, maka akan timbullah dalam hati nurani si pelanggar itu rasa penyesalan, rasa malu, takut, dan merasa bersalah.

Daerah berlakunya norma etik relatif universal, meskipun tetap dipengaruhi oleh ideologi masyarakat pendukungya. Perilaku membunuh adalah perilaku yang amoral, asusila atau tidak etis. Pandangan itu bisa diterima oleh orang dimana saja atau universal. Namun, dalam hal tertentu, perilaku seks bebas bagi masyarakat penganut kebebasan kemungkinan bukan perilaku yang amoral. Etika masyarakat Timur mungkin berbeda dengan etika masyarakat barat.

Norma etik atau norma moral menjadi acuan manusia dalam berperilaku. Dengan norma etik, manusia bisa membedakan mana perilaku yang baik dan juga mana perilaku yang buruk. Norma etik menjadi semacam das sollen untuk berperilaku baik. Manusia yang beretika berarti perilaku manusia itu baik sesuai dengan norma-norma etik.

Budaya atau kebudayaan adalah hasil cipta, rasa dan karsa manusia. Manusia yang beretika akan menghasilkan budaya yang memiliki nilai-nilai etik pula. Etika berbudaya mengandung tuntutan atau keharusan bahwa budaya yang diciptakan manusia mengandung nilai-nilai etik yang kurang lebih bersifat universal atau diterima sebagian besar orang. Budaya yang memiliki nilai-nilai etik adalah budaya yang mampu menjaga, mempertahankan, bahakan mampu meningktkan harkat dan martabat manusia itu sendiri. Sebaliknya, budaya yang beretika adalah kebudayaan yang akan merendahkan atau bahkan menghancurkan martabat kemanusiaan.

Namun demikian, menentukan apakah suatu budaya yang dihasilkan manusia itu memenuhi nilai-nilai etik ataukah menyimpang dari nilai etika adalah bergantung dari paham atau ideologi yang diyakini masyarakat pendukung kebudayaan. Hal ini 
dikarenakan berlakunya nilai-nilai etik bersifat universal, namun amat dipengaruhi oleh ideologi masyarakatnya.

Contohnya, budaya perilaku berduaan dijalan antara sepasang muda mudi, bahkan bermesraan di hadapan umum. Masyarakat individual menyatakan hal demikian bukanlah perilaku yang etis, tetapi akan ada sebagian orang atau masyarakat yang berpandangan hal tersebut merupakan suatu penyimpangan etik.

\section{Estetika Manusia dalam Berbudaya}

Estetika dapat dikatakan sebagai teori tentang keindahan atau seni. Estetika berkaitan dengan nilai indah-jelek (tidak indah). Nilai estetika berari nilai tentang keindahan. Keindahan dapat diberi makna secara luas, secara sempit, dan estetik murni.

a. Secara luas keindahan mengandung ide kebaikan, bahwa segala sesuatunya yang baik termasuk yang abstrak maupun nyata yang mengandung ide kebaikan adalah indah. Keindahan dalam arti luas meliputi banyak hal, seperti watak yang indah, hukum yang indah, ilmu yang indah, dan kebajikan yang indah. Indah dalam arti luas mencakup hampir seluruh yang ada apakah merupakan hasil seni, alam, moral, dan intelektual.

b. Secara sempit, yaitu indah yang terbatas pada lingkup persepsi penglihatan (bentuk dan warna).

c. Secara estetik murni, menyangkut pengalaman estetik seseorang dalam hubungannya dengan segala sesuatu yang diresapinya melalui penglihatan, pendengaran perabaan dan perasaan, yang semuanya dapat menimbulkan persepsi (anggapan) indah.

Jika estetika dibandingkan dengan etika, maka etika berkaitan dengan nilai tentang baik-buruk, sedangkan estetika berkaitan dengan hal yang indah-jelak. Sesuatu yang estetik berarti memenuhi unsur keindahan (secara estetik murni maupun secara sempit, baik dala bentuk, warna, garis, kata, ataupun nada). Budaya yang estetik berarti budaya tersebut memiliki unsur keindahan.

Apabila nilai etik bersifat relatif universal, dalam arti bisa diterima banyak orang, namun nilai estetik amat subjektif dan partikular. Sesuatu yang indah bagi seseorang belum tentu indah bagi orang lain. Misalkan dua orang memandang sebuah lukisan. 
Orang yang pertama akan mengakui keindahan yang terkandung dalam lukisan tersebut, namun bisa jadi orang kedua sama sekali tidak menemukan keindahan di lukisan tersebut.

Oleh karena subjektif, nilai estetik tidak bisa dipaksakan pada orang lain. Kita tidak bisa memaksa seseorang untuk mengakui keindahan sebuah lukisan sebagaimana pandangan kita. Nilai-nilai estetik lebih bersifat perasaan, bukan pernyataan.

Budaya sebagai hasil karya manusia sesungguhnya diupayakan untuk memenuhi unsur keindahan. Manusia sendiri memang suka akan keindahan. Di sinilah manusia berusaha berestetika dalam berbudaya. Semua kebudayaan pastilah dipandang memiliki nilai-nilai estetik bagi masyarakat pendukung budaya tersebut. Hal-hal yang indah dan kesukaannya pada keindahan diwujudkan dengan menciptakan aneka ragam budaya.

Namun sekali lagi, bahwa suatu produk budaya yang dipandang indah oleh masyarakat pemiliknya belum tentu indah bagi masyarakat budaya lain. Contohnya, budaya suku-suku bangsa Indonesia. Tarian suatu suku berikut penari dan pakaiannya mungkin dilihat tidak ada nilai estetikanya, bahkan dipandang aneh oleh warga dari suku lain, demikian pula sebaliknya.

Oleh karena itu, estetika berbudaya tidak semata-mata dalam berbudaya harus memenuhi nilai-nilai keindahan. Lebih dari itu, estetika berbudaya menyiratkan perlunya manusia (individu atau masyarakat) untuk menghargai keindahan budaya yang dihasilkan manusia lainya. Keindahan adalah subjektif, tetapi kita dapat melepas subjektivitas kita untuk melihat adanya estetika dari budaya lain. Estetika berbudaya yang demikian akan mampu memecah sekat-sekat kebekuan, ketidak percayaan, kecurigaan, dan rasa inferioritas antar budaya.

\section{B. Memanusiakan Manusia}

Manusia tidak hanya sebatas menjadi homo, tetapi harus meningkatkan diri menjadi human. Manusia harus memiliki prinsip, nilai, dan rasa kemanusiaan yang melekat dalam dirinya. Manusia memiliki perikemanusiaan, tetapi binatang tidak bisa dikatakan memiliki perbintangan. Hal ini karena binatang tidak memiliki akal budi, 
sedangkan manusia memiliki akal budi yang bisa memunculkan rasa atau perikemanusiaan. Perikemanusiaan inilah yang mendorong perilaku baik sebagai manusia.

Memanusiakan manusia berarti perilaku manusia untuk seantiasa menghargai dan menghormati harkat dan derajat manusia lainnya. Memanusiakan manusia memberi keuntungan bagi diri sendiri maupun orang lan. Bagi diri sendiri akan menunjukan harga diri dan nilai luhur pribadinya sebagai manuia. Sedangkan bagi orang lain akan memberikan rasa percaya, rasa hormat, kedamaian, dan kesejahteraan hidup.

Sebaliknya, sikap tidak manusiawi terhadap manusia lain hanya akan merendahkan harga diri dan martabatnya sebagai manusia yang sesungguhnya makhluk mulia. Sedangkan bagi orang lain sebagai korban tindakan yang tidak manusiawi akan menciptakan penderitaan, kesusahan, ketakutan, perasaan dendam, dan sebagainya. Sejarah membuktikan bahwa perseteruan, pertentangan, dan peperangan terjadi diberbagai belahan dunia adalah karena manusia belum mampu memanusiakan manusia lain, dan sekelompok bangsa menindas bangsa lain. Penjajahan atau kolonialisme adalah contoh prilaku satu bangsa menindas bangsa lain. Penjajahan tidak sesuai dengan peri kemanusiaan.

Dewasa ini, perilaku tidak manusiawi dicontohkan dengan adanya kasus kekerasaan terhadap para pembantu rumah tangga. Misalkan seorang pembantu disiksa, tidak diberi upah, dikurung dalam rumah,dan sebagainya. Para majikan telah melakukan tindakan yang bertentangan dengan prinsip-prinsip kemanusiaan.

Sikap dan perilaku memanusiakan manusia didasarkan atas prinsip kemanusiaan yang disebut the mankind is one. Prinsip kemanusiaan tidak membeda-bedakan kita memperlakukan orang lain atas dasar warna kulit,suku,agama,ras,asal,dan status sosial ekonomi. Kita tetap harus manusiawi terhadap orang lain, apa pun latar belakangnya, karena semua manusia adalah makhluk Tuhan yang sama harkat dan martabatnya. Perilaku yang manusiawi atau memanusiakan manusia adalah sesuai dengan kodrat manusia. Sebaliknya, perilaku yang tidak manusiawi bertentangan dengan hakikat kodrat manusia. Perilaku yang tidak manusiawi akan mendatangkan kerusakan hidup manusia. 


\section{Senarai (summary)}

Etika adalah ajaran tentang baik-buruk, yang diterima umum atau tentang sikap, perbuatan, kewajiban, dan sebagainya. Etika bisa disamakan artinya dengan moral (mores dalam bahasa latin), akhlak, atau kesusilaan. Etika berkaitan dengan masalah nilai, karena etika pada pokoknya membicarakan masalah-masaah yang berkaitan dengan predikat nilai susila, atau tidak susila, baik dan buruk. Estetika dapat dikatakan sebagai teori tentang keindahan atau seni. Estetika berkaitan dengan nilai indah-jelek (tidak indah). Nilai estetika berari nilai tentang keindahan

Sikap dan perilaku memanusiakan manusia didasarkan atas prinsip kemanusiaan yang disebut the mankind is one. Prinsip kemanusiaan tidak membeda-bedakan kita memperlakukan orang lain atas dasar warna kulit,suku,agama,ras,asal,dan status sosial ekonomi karena semua manusia adalah makhluk Tuhan yang sama harkat dan martabatnya. Perilaku yang manusiawi atau memanusiakan manusia adalah sesuai dengan kodrat manusia. Sebaliknya, perilaku yang tidak manusiawi bertentangan dengan hakikat kodrat manusia. Perilaku yang tidak manusiawi akan mendatangkan kerusakan hidup manusia. 


\section{BAHAN AJAR}

\section{SESSI/PERKULIAHAN KE 4}

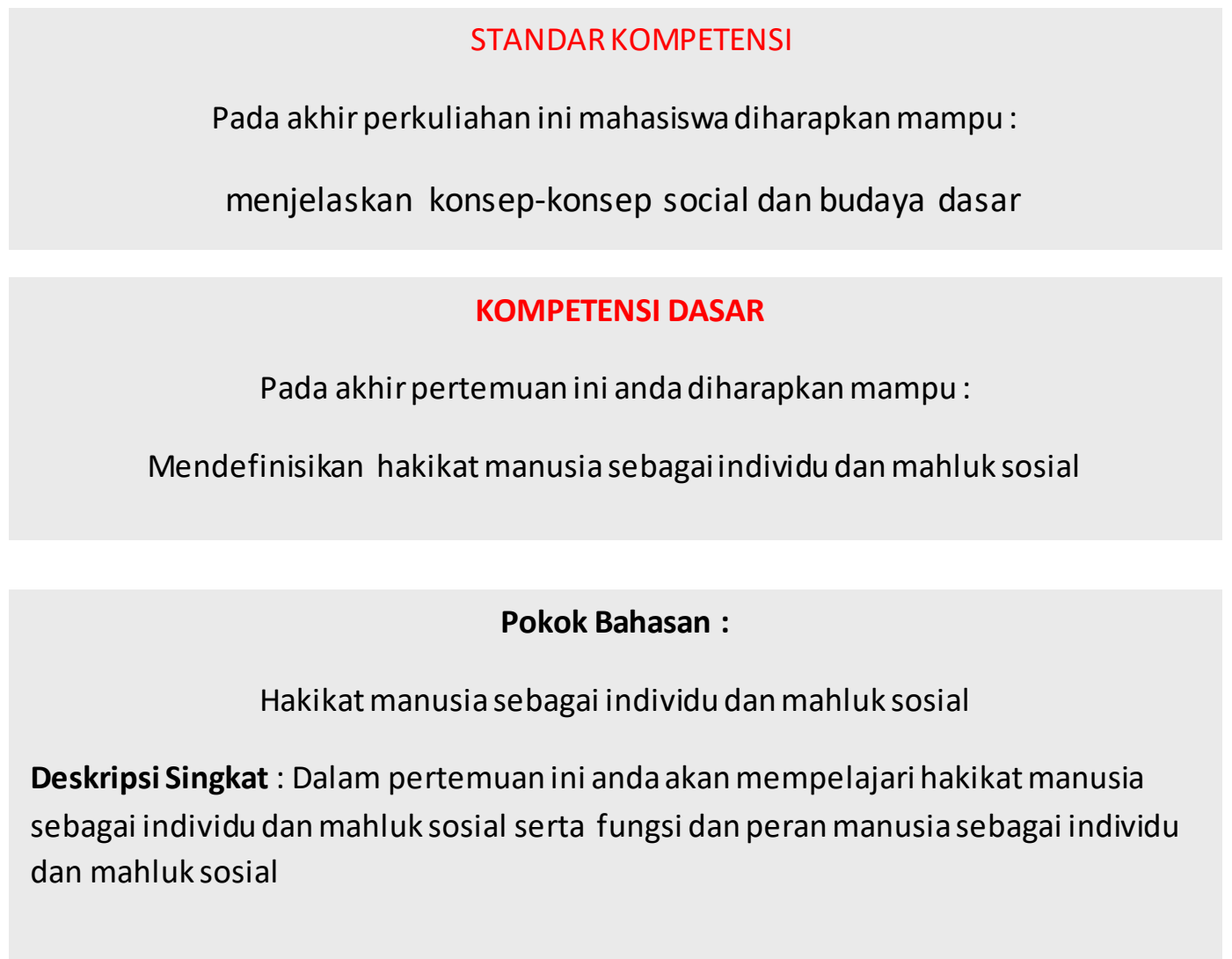

\section{Buku / bacaan wajib (bw)}

1. Sudiran, Florentinus. 2011. Ilmu Sosial Dasar. Laksbang : Jogyakarta

2. Setiadi, Elly M. dkk. 2006.. Ilmu Sosial Dasar Kencana. Jakarta

3. Schuon, F. 1997. Hakikat Manusia. Pustaka Pelajar. Yogakarta.

4. Soekanto, Soejono. 1983. Struktur Masyarakat. Rajawali. Jakarta.

5. Suleman, munandar. 1995. Ilmu Budaya Dasar. Eresco. Bandung

\section{Buku /bacaan anjuran (ba)}

1. Burhanuddin. 1988. Filsafat Manusia (Antropologi Metafisika). Bina Aksara. Jakarta

2. Baker, A. 1992. Ontologi: Metafisika Umum. Kanisius. Yogyakarta.

3. Geerzt, H. 1980. Aneka Budaya dan Komunitas di Indonsia. Yis dan FIS UI. Jakarta. 
4. Kuntowijoyo. 1990. Metodologi Sejarah. Tiara Wacana. Yogakarta.

\section{Pertanyaan kunci/ tugas}

Ketika anda membaca bahan bacaan berikut, gunakan pertanyaan-pertanyaan berikut ini untuk memandu anda :

1. Jelaskan Hakikat manusia sebagai individu dan mahluk sosial

2. Jelaskan Fungsi dan peran manusia sebagai individu dan mahluk sosial

\section{Tugas}

Untuk memperdalam pemahaman anda mengenai materi di atas, silahkan mengerjakan Tugas, sebagai berikut :

1. Coba diskusikan dengan teman-teman anda dimaksud Hakikat manusia sebagai individu dan mahluk sosial serta fungsi dan peran manusia sebagai individu dan mahluk sosial

2. Buatlah sumary dari perkuliahan ini dan presentasikan di pertemuan perkuliahan selanjutnya.

\section{MATERI PENYAJIAN}

Perkuliahan yang menyajikan materi hakikat manusia sebagai individu dan mahluk sosial dan materi fungsi dan peran manusia sebagai individu dan mahluk sosial. Pada materi hakikat manusia sebagai individu dan mahluk sosial dijelaskan pengertian hakikat manusia, pengertian manusia sebagai makhluk individu, dan makhluk Sosial Kemudia jelaskan pula mengenai fungsi dan peranan manusia sebagai makhluk individu dan social

\section{A. Hakikat Manusia Sebagai Individu}

\section{Pengertian Hakikat Manusia}

Hakekat manusia adalah sebagai berikut :

a. Makhluk yang memiliki tenga dalam yang dapat menggerakkan hidupnya untuk memenuhi kebutuhan-kebutuhannya.

b. Individu yang memiliki sifat rasional yang bertanggung jawab atas tingkah laku intelektual dan sosial. 
c. yang mampu mengarahkan dirinya ke tujuan yang positif mampu mengatur dan mengontrol dirinya dan mampu menentukan nasibnya.

d. Makhluk yang dalam proses menjadi berkembang dan terus berkembang tidak pernah selesai (tuntas) selama hidupnya.

e. Individu yang dalam hidupnya selalu melibatkan dirinya dalam usaha untuk mewujudkan dirinya sendiri, membantu orang lain dan membuat dunia lebih baik untuk ditempati

f. Suatu keberadaan yang berpotensi yang perwujudanya merupakan ketakterdugaan dengan potensi yang tak terbatas

g. Makhluk Tuhan yang berarti ia adalah makhluk yang mengandung kemungkinan baik dan jahat.

h. Individu yang sangat dipengaruhi oleh lingkungan turutama lingkungan sosial, bahkan ia tidak bisa berkembang sesuai dengan martabat kemanusaannya tanpa hidup di dalam lingkungan sosial.

\section{Pengertian Manusia Sebagai Makhluk Individu}

Manusia, mahluk dan individu secara etimologi diartikan sebagai berikut:

1. Manusia berarti mahluk yang berakal budi dan mampu menguasai mahluk lain.

2. Mahluk yaitu sesuatu yang diciptakan oleh Tuhan.

3. Individu mengandung arti orang seorang, pribadi, organisme yang hidupnya berdiri sendiri. Secara fisiologis ia bersifat bebas, tidak mempunyai hubungan organik dengan sesama.

Kata manusia berasal dari kata manu (Sansekerta) atau mens (Latin) yang berarti berpikir, berakal budi, atau homo (Latin) yang berarti manusia. Istilah individu berasal dari bahasa Latin, yaitu individum, yang artinya sesuatu yang tidak dapat dibagi-bagi lagi atau suatu kesatuan yang terkecil dan terbatas.

Secara kodrati, manusia merupakan mahluk monodualis. Artinya selain sebagai mahluk individu, manusia berperan juga sebagai mahluk sosial. Sebagai mahluk individu, manusia merupakan mahluk ciptaan Tuhan yang terdiri atas unsur jasmani (raga) dan rohani (jiwa) yang tidak dapat dipisah-pisahkan. Jiwa dan raga inilah yang membentuk individu. 
Manusia juga diberi kemampuan (akal, pikiran, dan perasaan) sehingga sanggup berdiri sendiri dan bertanggung jawab atas dirinya. Disadari atau tidak, setiap manusia senantiasa akan berusaha mengembangkan kemampuan pribadinya guna memenuhi hakikat individualitasnya (dalam memenuhi berbagai kebutuhan hidupnya). Hal terpenting yang membedakan manusia dengan mahluk lainnya adalah bahwa manusia dilengkapi dengan akal pikiran, perasaan dan keyakinan untuk mempertinggi kualitas hidupnya. Manusia adalah ciptaan Tuhan dengan derajat paling tinggi di antara ciptaanciptaan yang lain.

\section{Hakikat Manusia Sebagai Makhluk Individu}

Individu berasal dari kata in dan devided. Dalam Bahasa Inggris in salah satunya mengandung pengertian tidak, sedangkan devided artinya terbagi. Menurut pendapat Dr. A. Lysen individu berasal dari bahasa latin individum, yang artinya tak terbagi. Kata individu merupakan sebutan yang dipakai untuk meyatakan satu kesatuan yang paling kecil dan terbatas. Kata individu bukan berarti manusia secara keseleruhan yang tak dapat dibagi, melainkan sebagai kesatuan terbatas, yaitu perseorangan manusia. Individu menekankan penyelidikan kepada kenyataan-kenyataan hidup yang istimewa, dan seberapa mempengaruhi kehidupan manusia. Individu bukan berarti manusia sebagai suatu keseluruhan yang tak dibagi, melainkan sebagai kesatuan yang terbatas, yaitu sebagai manusia perorangan sehingga sering disebut "orang seorang" atau "manusia perseorangan". Individu dalam hal ini adalah seorang manusia yang tidak hanya memiliki peranan-peranan yang khas di dalam lingkungan sosialnya, melainkan juga mempunyai kepribadian serta pola tingkahlaku spesifik tentang dirinya. Akan tetapi dalam banyak hal banyak pula persamaan disamping hal-hal yang spesifik tentang dirinya dengan orang lain.

Disini jelas bahwa individu adalah seorang manusia yang tidak hanya memiliki peranan khas didalam lingkungan sosaialnya, melainkan juga mempunyai kepribadian, serta pola tingkah laku spesifik dirinya. Persepsi terhadap individu atau hasil pengamatan manusia dengan segala maknanya merupakan suatu keutuhan ciptaan Tuhan yang mempunyai tiga aspek yang melekat pada dirinya, yaitu aspek organik jasmaniah, aspek psikis rohaniah, dan aspek sosial. Apabila terjadi kegoncangan pada salah satu aspek, maka akan membawa akibat pada aspek yang lainnya. 
Individu dalam tingkahlaku menurut pola pribadinya memiliki tiga kemungkinan:

1. Menyimpang dari norma kolektif kehilangan individualitasnya.

2. Takluk terhadap kolektif.

3. Ketiga mempengaruhi masyarakat.

Manusia sebagai makhluk individu memiliki unsur jasmani dan rohani, unsur fisik dan psikis, unsur raga dan jiwa. Seseorang dikatakan sebagai manusia individu manakala unsur-unsur tersebut menyatu dalam dirinya. Jika unsur tersebut sudah tidak menyatu lagi maka seseorang tidak disebut sebagai individu. Dalam diri individu ada unsur jasmani dan rohaninya, atau ada unsur fisik dan psikisnya, atau ada unsur raga dan jiwanya.

Manusia dikatakan menjadi individu apabila pola tingkah lakunya sudah bersifat spesifik didalam dirinya dan bukan lagi menuruti pola tingkahlaku umum.

Didalam sebuah massa manusia cenderung menyingkirkan individu alitasnya karena tingkah lakunya adalah hampir identik dengan tingkahlaku massa yang bersangkutan. Dalam hubungan ini dapat dicirikan, apabila manusia dalam tindakan-tindakannya menjurus kepada kepentingan pribadi maka disebut manusia sebagai makhluk individu, sebaliknya apabila tindakan-tindakannya merupakan hubungan dengan manusia lainnya, maka manusia itu dikatakan makhluk sosial. Pengalaman menunjukkan bahwa jika seseorang pengabdiannya kepada diri sendiri besar, maka pengabdiannya kepada masyarakat kecil. Sebaliknya jika seseorang pengabdiannya kepada diri sendiri kecil, maka pengabdiannya kepada masyarakat besar. Dengan demikian dapatlah dikatakan bahwa proses yang dikatakan bahwa yang meningkatkan ciri-ciri individualitas pada seseorang sampai ia adalah dirinya sendiri, disebut sebagai proses individualitas, atau kadang-kadang juga diberi nama proses aktualisasi diri.

\section{Pengertian Manusia Sebagai Makhluk Sosial}

Manusia sebagai makhluk sosial adalah manusia yang senantiasa hidup dengan manusia lain (masyarakatnya). Ia tidak dapat merealisasikan potensi hanya dengan dirinya sendiri. Manusia akan membutuhkan manusia lain untuk hal tersbut, termasuk dalam mencukupi kebutuhannya. 
Ketika manusia sebagai makhluk individu ternyata tidak mampu hidup sendiri. Pada usia bayi, ia sudah menjalin hubungan terutama dengan ayah dan ibu, dalam bentuk gerakan, senyuman, dan kata-kata. Pada usia 4 tahun, ia mulai berhubungan dengan teman- teman sebaya dan melakukan kontak sosial. Pada usia-usia selanjutnya, ia terikat dengan norma-norma pergaulan dengan lingkungan yang semakan luas. manusia hidup dalam lingkungan sosialnya. Ia dalam menjalani kehidupannya akan senantiasa bersama dan bergantung pada manusia lainnya. Manusia saling membutuhkan dan harus bersosialisasi dengan manusia lainnya. Hal ini disebabkan manusia dalam memenuhi kebutuhan hidupnya tidak dapat memenuhinya sendiri. Ia akan bergabung dengan manusia lain membentuk kelompok-kelompok dalam rangka pemenuhan kebutuhan dan tujuan hidup. Dalam hal ini, manusia sebagai individu memasuki kehidupan bersama dengan individu lainnya.

Berdasarkan proses diatas, manusia lahir dengan keterbatasan, dan secara naluriah manusia membutuhkan hidup dengan manusia lainnya. Manusia sejak lahir dipeliharadan dibesarkan dalam sesuatu masyarakat terkecil, yaitu keluarga. Keluarga terbentuk karena adanya pergaulan antar anggota sehingga dapat dikatakan bahwa berkeluarga merupakakan kebutuhan manusia. Esensinya, manusia memerlukan orang lain atau hidup hidup dalam kelompoknya.

Cooley berpendapat, ia memberi nama looking-glass self untuk melihat bahwa seseorang dipengaruhi oleh orang lain. Nama demikian diberikan olehnya karena melihat analogi antara pembentukan diri seseorang dengan perilaku orang yang sedang bercermin; kalau cermin memantau apa yang ada didepannya, maka menurut Cooley diri seseorang memantau apa yang di rasakannya sebagai tanggapan masyarakat terhadapnya.

\section{B. Fungsi dan Peranan Manusia Sebagai Makhluk Individu dan Sosial}

Manusia sebagai pribadi adalah berhakikat sosial. Artinya, manusia akan senantiasa dan selalu berhubungan dengan orang lain. Manusia tidak mungkin hidup sendiri tanpa bantuan orang lain. Fakta ini memberikan kesadaran akan "ketidakberdayaan" manusia dalam memenuhi kebutuhannya sendiri.

Kebutuhan akan orang lain dan interaksi sosial membentuk kehidupan berkelompok pada manusia. Berbagai kelompok sosial tumbuh seiring dengan kebutuhan 
manusia untuk saling berinteraksi. Dalam berbagai kelompok sosial ini, manusia membutuhkan norma-norma pengaturannya. Terdapat norrma-norma sosial sebagai patokan untuk bertingkah laku bagi manusia di kelompoknya. Norma-norma tersebut ialah:

a. Norma agama atau religi, yaitu norma yang bersumber dari Tuhan yang diperuntukkan bagi umat-Nya. Norma agama berisi perintah agar dipatuhi dan larangan agar dijauhi umat beragama. Norma agama ada dalam ajaran-ajaran agama.

b. Norma kesusilaan atau moral, yaitu norma yang bersumber dari hati nurani manusia untuk mengajak kepada kebaikan dan menjauhi keburukan. Norma moral bertujuan agar manusia berbuat baik secara moral. Orang berkelakuan baik adalah orang yang bermoral, sedangkan orang yang berkelakuan buruk adalah orang tidak bermoral atau amoral.

c. Norma kesopanan atau adat adalah norma yang bersumber dari masyarakat dan berlaku terbatas pada lingkungan masyarakat yang bersangkutan. Norma ini di maksudkan untuk menciptakan keharmonisan hubungan antarsesama.

d. Norma hukum, yaitu norma yang dibuat masyarakat secara remi (negara) yang pemberlakuannya dapat dipaksakan. Norma hukum yang brsifat tertulis.

Selain itu, norma dapat dibedakan pula menjadi empat macam berdasarkan kekuatan berlakunya dimasyarakat. Ada norma yang daya ikatnya sangat kuat, sedang, dan ada pula norma yang daya ikatnya sangat lemah. Keempat jenis tersebut adalah cara (usage), kebiasaan (folkways), tata kelakuan (mores), dan adat istiadat (costum).

\section{Senarai (summary)}

Kata manusia berasal dari kata manu (Sansekerta) atau mens (Latin) yang berarti berpikir, berakal budi, atau homo (Latin) yang berarti manusia. Istilah individu berasal dari bahasa Latin, yaitu individum, yang artinya sesuatu yang tidak dapat dibagi-bagi lagi atau suatu kesatuan yang terkecil dan terbatas. secara naluriah manusia membutuhkan hidup dengan manusia lainnya. Manusia sejak lahir dipeliharadan dibesarkan dalam sesuatu masyarakat terkecil, yaitu keluarga. Manusia akan senantiasa dan selalu berhubungan dengan orang lain. Manusia tidak mungkin hidup sendiri tanpa bantuan orang lain. Fakta ini memberikan kesadaran akan "ketidakberdayaan" manusia dalam memenuhi kebutuhannya sendiri. 


\section{DAFTAR PUSTAKA}

Sudiran, Florentinus. 2011. Ilmu Sosial Dasar. Laksbang : Jogyakarta

Setiadi, Elly M. dkk. 2007. Ilmu Sosial Dasar Kencana. Jakarta

Sulfemi, Wahyu Bagja. (2007). Ilmu Sosial Dasar. Bogor : STKIP Muhamadiyah Bogor

Schuon, F. 1997. Hakikat Manusia. Pustaka Pelajar. Yogakarta.

Soekanto, Soejono. 1983. Struktur Masyarakat. Rajawali. Jakarta.

Suleman, munandar. 1995. Ilmu Budaya Dasar. Eresco. Bandung

Baker, A. 1992. Ontologi: Metafisika Umum. Kanisius. Yogyakarta.

Geerzt, H. 1980. Aneka Budaya dan Komunitas di Indonsia. Yis dan FIS UI. Jakarta.

Kuntowijoyo. 1990. Metodologi Sejarah. Tiara Wacana. Yogakarta. 